Synthesis Paper

\title{
Incorporating Biodiversity Into Rangeland Health: Plant Species Richness and Diversity in Great Plains Grasslands
}

\author{
Amy J. Symstad ${ }^{1}$ and Jayne L. Jonas ${ }^{2}$ \\ Authors are ${ }^{1}$ Research Ecologist, Northern Prairie Wildlife Research Center, US Geological Survey, Hot Springs, SD 57747, USA; and ${ }^{2}$ Post-Doctoral \\ Research Assistant, Department of Forestry, Rangeland and Watershed Stewardship, Colorado State University, Fort Collins, CO 80523, USA.
}

\begin{abstract}
Indicators of rangeland health generally do not include a measure of biodiversity. Increasing attention to maintaining biodiversity in rangelands suggests that this omission should be reconsidered, and plant species richness and diversity are two metrics that may be useful and appropriate. Ideally, their response to a variety of anthropogenic and natural drivers in the ecosystem of interest would be clearly understood, thereby providing a means to diagnose the cause of decline in an ecosystem. Conceptual ecological models based on ecological principles and hypotheses provide a framework for this understanding, but these models must be supported by empirical evidence if they are to be used for decision making. To that end, we synthesize results from published studies regarding the responses of plant species richness and diversity to drivers that are of management concern in Great Plains grasslands, one of North America's most imperiled ecosystems. In the published literature, moderate grazing generally has a positive effect on these metrics in tallgrass prairie and a neutral to negative effect in shortgrass prairie. The largest published effects on richness and diversity were caused by moderate grazing in tallgrass prairies and nitrogen fertilization in shortgrass prairies. Although weather is often cited as the reason for considerable annual fluctuations in richness and diversity, little information about the responses of these metrics to weather is available. Responses of the two metrics often diverged, reflecting differences in their sensitivity to different types of changes in the plant community. Although sufficient information has not yet been published for these metrics to meet all the criteria of a good indicator in Great Plains Grasslands, augmenting current methods of evaluating rangeland health with a measure of plant species richness would reduce these shortcomings and provide information critical to managing for biodiversity.
\end{abstract}

\section{Resumen}

Los indicadores de la salud de los pastizales generalmente no incluyen una medida de la biodiversidad. El aumento en la atención de mantener la biodiversidad en los pastizales sugiere que esta omisión sea reconsiderada. La riqueza y la diversidad de las especies de plantas son dos parámetros que pueden ser muy útiles y apropiados. Idealmente, su respuesta a una variedad de factores antropogénicos y naturales en el ecosistema de interés se podría entender claramente, proporcionando los medios para diagnosticar la causa del detrimento del ecosistema. Los modelos ecológicos conceptuales basados en principios e hipótesis ecológicos proporcionan un marco para esta comprensión, pero estos modelos deben ser apoyados por evidencias empíricas si van a ser utilizados para la toma de decisiones. De tal manera, resumimos los resultados de estudios publicados con respecto a las respuestas de la riqueza y de la diversidad de las especies de plantas y los factores que son de preocupación a los manejadores de los pastizales de las grandes planicies, uno de los ecosistemas más amenazado de Norte América. En la literatura publicada, el pastoreo moderado generalmente tiene un efecto positivo en estos parámetros en los pastizales altos y un efecto neutro o negativo en los pastizales cortos. La mayoría de las publicaciones sobre la riqueza y diversidad de los pastizales fueron causadas por el pastoreo moderado en los pastizales altos y la fertilización de nitrógeno en los pastizales cortos. Aunque, el clima se cita frecuentemente como la razón de las fluctuaciones anuales considerables en la riqueza y la diversidad, poca información sobre las respuestas de estos parámetros al clima está disponible. Las respuestas de los dos parámetros difirieron a menudo, reflejando discrepancias en su sensibilidad a diversos tipos de cambios en la comunidad de la planta. Aunque suficiente información todavía no se ha publicado para que estos dos parámetros cubran todos los criterios de un buen indicador de los pastizales de las grandes planicies, el incluir en los métodos actuales de evaluación de la salud de los pastizales, una medida de riqueza de las especies de las plantas reduciría estos defectos y proporcionaría la información crítica para el manejo de la biodiversidad.

Key Words: climate, fire, grazing, indicator, nitrogen fertilization, prairie dogs

Research was funded by the US Geological Survey, National Parks Monitoring Project.

Any use of trade, product, or firm names is for descriptive purposes only and does not imply endorsement by the US Government.

At the time of research, Jonas was a research scientist, IAP World Services, Inc, Brighton, C0 80601, USA.

Amy J. Symstad and Jayne L. Jonas made an equal contribution to this paper.

Correspondence: Amy J. Symstad, Wind Cave National Park, 26611 US Highway 385, Hot Springs, SD 57747, USA. Email: asymstad@usgs.gov

Manuscript received 24 August 2010; manuscript accepted 6 July 2011. 


\section{INTRODUCTION}

Although many systems for evaluating rangeland health ("The degree to which the integrity of the soil, vegetation, water, and air as well as the ecological processes of the rangeland ecosystem are balanced and sustained"; USDA-NRCS 1997) exist (e.g., Adams et al. 2003; Pellant et al. 2005; Ludwig and Bastin 2008), many do not include a measure of biodiversity as one of their indicators. For example, technical guidance for rangeland health evaluation in the United States includes indices of soil stability and hydrologic function (e.g., bare ground cover, soil macro-aggregate stability in water, water flow patterns, gullying), as well as biotic integrity. The biotic integrity indicators include cover and production of plant functional groups (including invasives) but do not measure the number of species present or their relative abundance. Species richness (the number of species in a given area, often a sample plot) and diversity (a combination of richness and the evenness or equitability of species' relative abundance, measured with a variety of diversity indices) are two metrics of biodiversity that have been proposed as indicators of ecosystem health in a variety of contexts (Costanza 1992; Fancy et al. 2009; Schimel et al. 2009). Plant species richness or diversity could therefore be expected to be an important indicator of rangeland health. However, compared to structural and functional indicators, these metrics have received relatively little attention in rangeland ecology, ecological site state-and-transition models, and recommended methods for evaluating rangeland health (Flather and Sieg 2000; Pellant et al. 2005; but see Whitford et al. 1998; Bai et al. 2001).

Three factors suggest that this omission should be reconsidered. Rapport et al. (1985) reported that a reduction in species diversity is one of the most widespread responses of an ecosystem to a stress with which it has not evolved, and evidence since then has supported this assertion (Zvereva et al. 2008). Similarly, Briske and colleagues (2006) proposed species loss as one category of threshold that rangelands cross when progressing from a desirable state to an undesirable state. Finally, rangeland and other ecologists have long suggested that a diverse mixture of species provides stability of biomass production through the compensatory reactions of different species or functional groups to fluctuating weather conditions (e.g., McNaughton 1977; Archer and Smeins 1991). A large body of research investigating the relationship between biodiversity and ecosystem functioning over the last $15 \mathrm{yr}$ has provided ample evidence to support this and other important roles of biodiversity. Numerous grassland studies have shown that mixtures of species generally yield greater aboveground biomass than the average monoculture, with at least some of this effect being caused by complementary resource use among species (Tilman et al. 2001; Hooper et al. 2005; Balvanera et al. 2006; Cardinale et al. 2006, 2007; Fargione et al. 2007; Schmid et al. 2009). Moreover, these grassland experiments have shown that this overyielding, coupled with asynchronous fluctuations of functional groups and species through time, produce positive effects of plant species richness on aboveground production (Tilman et al. 2006; Hector et al. 2010) and that maintaining high levels of multiple ecosystem functions (e.g., nutrient retention and belowground carbon storage in addition to aboveground production) requires more species than maintaining a high level of just one ecosystem function (Hector and Bagchi 2007; Zavaleta et al. 2010).

Although the applicability of these experimental results to real-world systems has been questioned for a variety of reasons, Duffy (2009) argues that the experiments are actually more likely to underestimate the importance of biodiversity in providing ecosystem services than to overestimate this importance. For these and other reasons, rangeland managers must be concerned with biodiversity maintenance (West 1993; Toombs 2010), and plant species richness or diversity should therefore be considered as one component of rangeland health.

However, to be a useful indicator of ecosystem health, changes in the indicator should be easily interpreted by managers and decision makers (Jackson et al. 2000; Andreasen et al. 2001). Increasing bare ground and decreasing soil macroaggregate stability, for example, indicate greater susceptibility to erosion and poorer soil water infiltration, respectively, both of which compromise plant production and the ability of the rangeland to recover to a more desirable condition without substantial intervention (Whisenant 1999). Shifting functional group composition (e.g., from grass to shrub dominated) suggests that forage availability is decreasing. For richness and diversity to meet this condition, a thorough understanding of how they are affected by natural drivers and management actions in a variety of rangeland types is needed. In this paper, we evaluate the state of knowledge regarding this condition for Great Plains Grasslands (GPG), one of the most threatened ecosystems in North America (Samson and Knopf 1994).

Great Plains grasslands originally covered approximately 2 million $\mathrm{km}^{2}$ (Fig. 1). Graminoids comprise the majority of plant biomass in them, but forbs and woody species provide the majority of species, particularly in the eastern portion of the region (Collins et al. 1998; Towne and Kemp 2003, 2008). Two climatic gradients drive large-scale distribution of species and species assemblages. Increasing mean annual temperature from north to south (Risser et al. 1981) is reflected in generally increased abundance of warm-season $\left(\mathrm{C}_{4}\right)$ graminoids relative to cool-season $\left(\mathrm{C}_{3}\right)$ graminoids at lower latitudes within the region (Lauenroth et al. 1999). Increasing precipitation from west to east (Risser et al. 1981) is reflected in generally increasing productivity and species richness of plant assemblages along this gradient (Knapp and Smith 2001; Adler and Levine 2007).

Great Plains grasslands evolved and, prior to European settlement, were maintained by interactions between these climatic forces, periodic fire, grazing by large ungulates and, in the central and western portions, by prairie dogs (Cynomys spp.) (Axelrod 1985; Anderson 2006). The agents of these climate-disturbance drivers remain a large part of the GPG that have not been converted to row-crop agriculture, though their identity and intensity have changed. Except in some local areas, such as the Flint Hills region of Kansas and northern Oklahoma, fire has been all but removed from most private and many public lands. Widely ranging, highly mobile herds of native ungulates, primarily bison (Bison bison) and elk (Cervus elaphus), have been replaced by more tightly controlled, relatively stationary herds of domestic livestock (mostly cattle) in most intact GPG. Prairie dogs have largely been extirpated. With an already variable climate, climate change models predict that GPG will experience continued increases in mean 

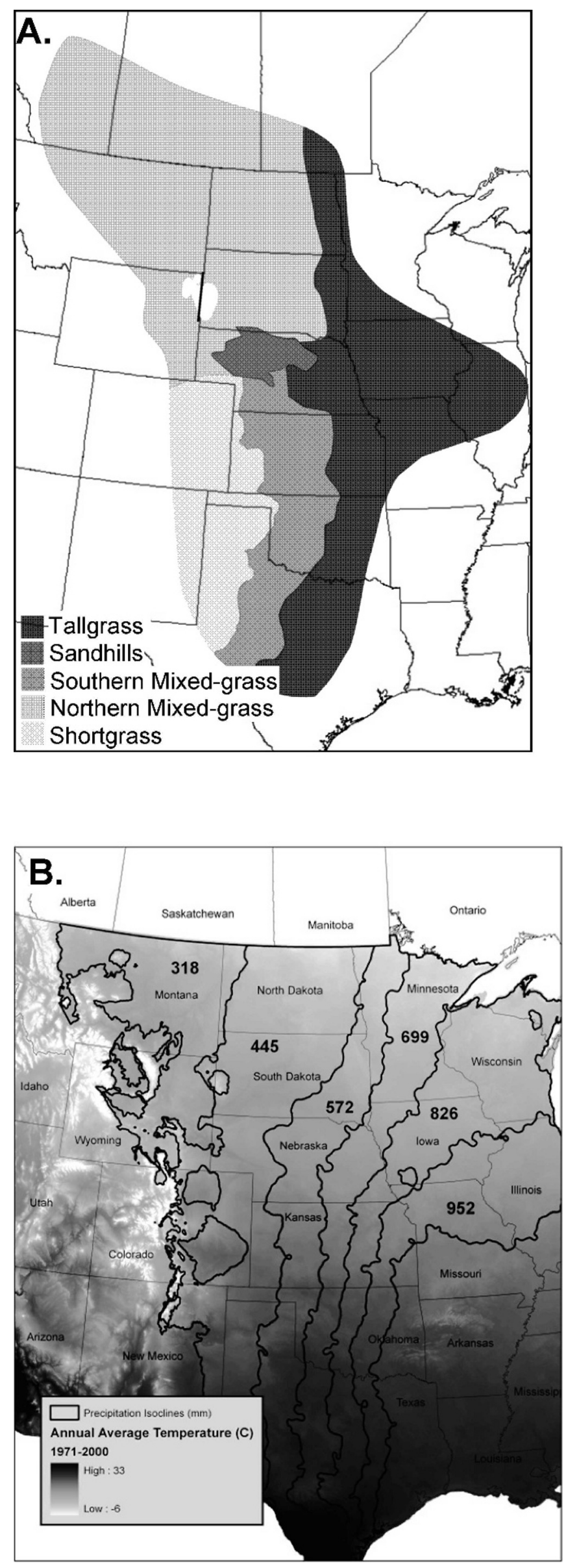

annual temperatures and more variable growing-season precipitation patterns (Christensen et al. 2007). Additional drivers associated with changes in land-use patterns, such as increased atmospheric deposition of nitrogen $(\mathrm{N})$ and introduction of exotic, sometimes invasive, species, also influence the plant assemblages in this region.

Although a large amount of research investigating the effect of many of these drivers on vegetation in these grasslands has been published, a comprehensive evaluation of driver-response relationships specifically for plant species richness and diversity in GPG has not been done. Our goals, therefore, are to 1) review and synthesize the published literature for plant species richness and diversity responses to various ecological drivers (climate/weather, prairie dogs, ungulate grazing, fire, and $\mathrm{N}$ fertilization) into conceptual models, 2) identify areas where sufficient evidence does not exist to confidently identify the strength or direction of a relationship between a driver and species richness or diversity, and 3) discuss the utility of richness and diversity as indicators of GPG health or condition based on these results.

\section{METHODS AND APPROACH}

We focus on the ecological drivers that are generally of greatest concern to land managers because they are directly under a local manager's control (fire regime, grazing regime, fertilization, prairie dog abundance) or are substantially impacted by local to global policy decisions (climate, atmospheric $\mathrm{N}$ deposition rates) or surrounding land management practices (exotic species). However, we acknowledge that other ecosystem components, such as arbuscular mycorrhizal fungi, insect herbivory, and disturbance associated with burrowing animals (other than prairie dogs), are also known to impact plant species richness or diversity in GPG (Martinsen et al. 1990; Hartnett and Wilson 2002; Branson and Sword 2009). We conducted an extensive literature review using the search terms "Great Plains," "grassland*," "prairie*," "richness," “diversity," "grazing," “fire,” “burn," "nitrogen fertilization," "nitrogen addition," "nitrogen deposition," "prairie dog*," "weather," "precipitation," "temperature," "exotic plant"," and "invasive plant"" singly and in various combinations in ISI Web of Science and Google Scholar. Initial search results were narrowed by assessing titles or abstracts. We also assessed articles cited by or citing the literature identified as pertinent to our review.

We concentrate on species richness and diversity; therefore, plant species richness and plant species diversity hereafter will be referred to as simply "richness" and "diversity." Although biodiversity at a variety of scales is linked to ecosystem functioning, we focus on richness and diversity at the plot or transect scale (i.e., alpha diversity) as opposed to turnover in species among habitats (beta diversity) or species richness or diversity at the landscape scale because quantitative informa-

\section{$\leftarrow$}

Figure 1. A, Great Plains grassland types, adapted from Lauenroth et al. (1999). B, Average annual precipitation (isoclines) and average annual maximum temperature (shading) in the Great Plains. Climate data were obtained from the PRISM Climate Group, Oregon State University, http://www.prismclimate.org, and were created 16 June 2006. 

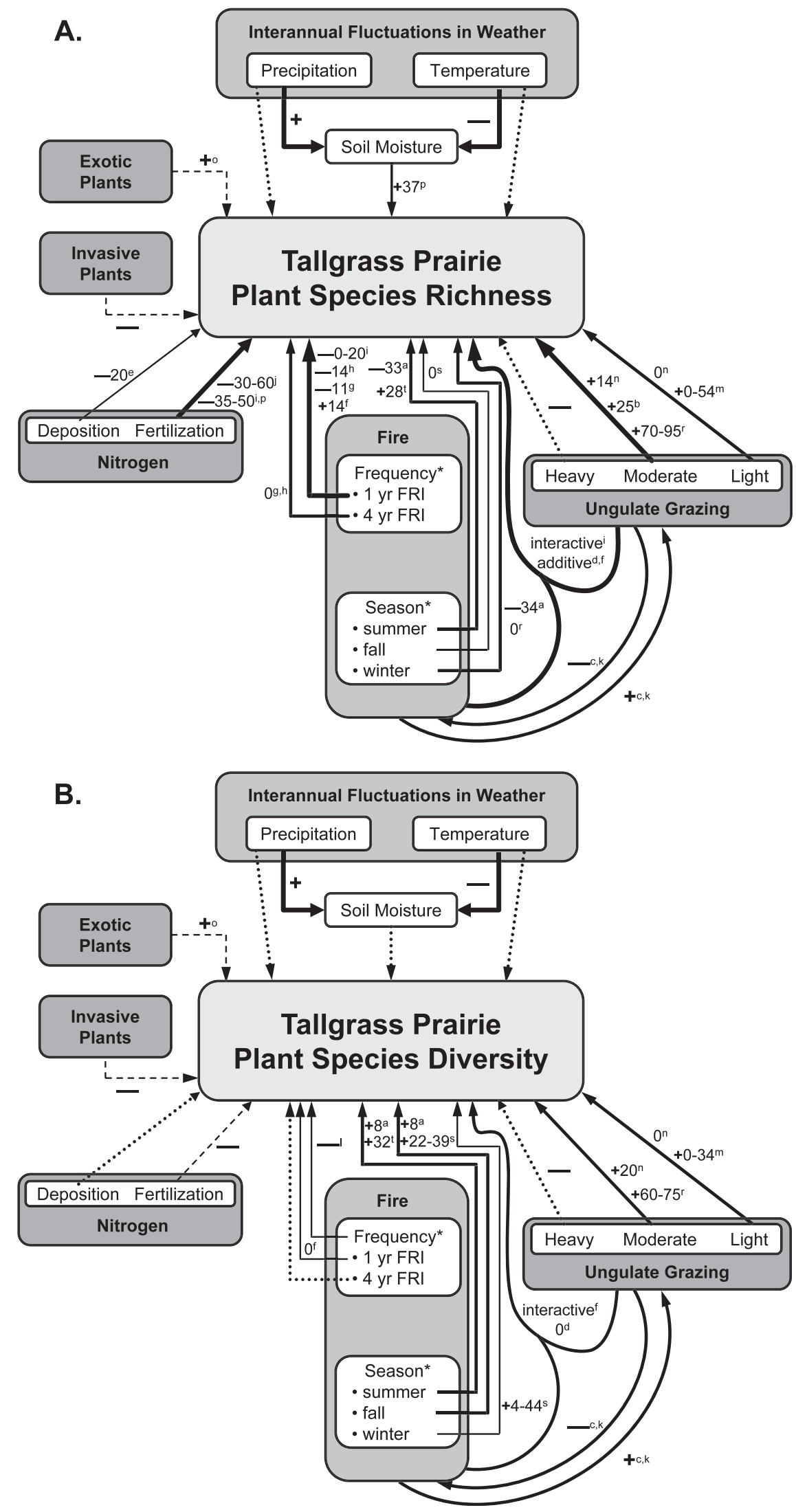

Figure 2. Conceptual model summarizing published information on effects of natural and anthropogenic drivers on plant species richness (A) and diversity (B) in high-productivity grasslands (tallgrass prairie) within the Great Plains region. Dotted connectors indicate an effect may exist, but no data or ecosystem-specific theory or data were found; dashed connectors indicate an effect derived from published theory; and solid lines indicate published data are available, with the thickness of the arrow increasing with the number of supporting studies. Percent increase $(+)$, decrease $(-)$, or lack of change $(0)$ in richness or diversity reported by individual studies (superscripts refer to sources in Supplementary Information, available at 
tion and statistical comparisons are most available for this scale. We recognize that richness and diversity may respond differently to a given ecological driver by reporting their results separately and compiling different conceptual models for each. We do not separate among various diversity indices, but we do indicate which index was used in each study. It should be noted that, because richness is measured on a linear scale, but diversity is measured on a variety of scales (often incorporating logarithmic and/or exponential values), a given percentage change in richness is not directly comparable to that same percentage change in diversity.

Because of the differences among plant assemblages along the productivity-precipitation gradient in GPG (Fig. 1) and differences in how their diversity is affected by various drivers, our review and synthesis models distinguish among higher productivity grasslands (i.e., tallgrass prairie in the eastern portion of the Great Plains) and lower productivity grasslands (i.e., shortgrass prairie in the western portion of the region) and the mixed-grass prairie between them.

\section{CLIMATE}

With a temperate, continental climate, GPG experience annual high temperatures during summers and low temperatures during winters (although these values vary considerably with latitude), with the majority of annual precipitation falling during the growing season (Borchert 1950). One of the defining climatological characteristics of the Great Plains region is extreme interannual variability in both temperature and precipitation (Borchert 1950). Many of the effects of these parameters on vegetation are driven by their effect on soil moisture, although direct effects of precipitation or temperature on factors such as germination cues and freezing mortality may also occur (Figs. 24). Although the plant assemblages of the region evolved under the pressure exerted by the unpredictable nature of the climate, their composition and productivity are by no means constant under these fluctuating conditions.

We focus on temporal fluctuations in climate for two reasons. First, interannual fluctuations in plant assemblages not directly associated with other environmental variables (fire, grazing, exotic species, etc.) may be at least partially caused by their inherent population dynamics (Tilman and Wedin 1991), but they are often attributed to the effects of weather (Gibson and Hulbert 1987; Coppedge et al. 1998). Therefore, a better understanding of the effects of these fluctuations on richness and diversity is critical to separating effects of management or anthropogenic stressors from this "noise." Second, understanding the responses of plant assemblages to these fluctuations may help predict their responses to climate changes that are expected to occur more rapidly than many species can migrate or adapt (Adler and Levine 2007).

Studies investigating the temporal relationship between precipitation and plant richness or diversity in GPG provide mixed results. In a northern tallgrass sand prairie, species richness declined by $37 \%$ following a near record drought and had not fully recovered after $2 \mathrm{yr}$ despite average or above-average annual precipitation (Tilman and El Haddi 1992). In Kansas tallgrass prairie, an experimental investigation yielded a $10-15 \%$ increase in plant diversity $\left(\mathrm{H}^{\prime}\right)$ when rainfall events occurred with $25 \%$ of the frequency but four times the intensity (amount of rainfall per event) of ambient conditions (Knapp et al. 2002). On the northern edge of the northern mixed grass prairie, species richness was positively correlated with precipitation (Wilson 2007). In central Kansas, species richness in little bluestem, shortgrass, or ecotone assemblages had little or no relationship to current year precipitation alone. Instead, species richness increased in years of normal or high precipitation following very dry years (Adler and Levine 2007). Whereas the patterns in this last study were attributed to possible effects of precipitation on germination cues for short-lived species, the rest of these studies measured or estimated soil moisture and attributed the precipitation effects to this ecosystem property.

We found no direct information on the influence of temporal fluctuations in temperature on richness or diversity of the whole plant assemblage in GPG. However, relationships between temperature and forb productivity or population growth of individual forb species provide a basis for postulating this influence, since forbs generally make up the majority of species richness in GPG. In one shortgrass study, increases in average summer minimum temperatures were positively correlated with the productivity of native forbs as a group (Alward et al. 1999). Another study using a 36-yr historical mixed-grass prairie dataset to assess fluctuations in the populations of 10 grassland forb species yielded variable results. Six species responded positively and four negatively to increases in dormant season temperature, whereas increased growing season temperature yielded positive responses in four species, negative responses in another four species, and a minimal response in two species (Adler and HilleRisLambers 2008).

Ecological theory and conceptual models directly addressing the impact of these fluctuations on richness and diversity are lacking (Adler and Levine 2007). Models relating plant species richness to climatic factors based on productivity gradients provide one possible framework for the development of this theory. For example, Laughlin and Moore (2009) suggested that richness may be greatest in years of intermediate production, when competitive dominance characteristic of high-productivity conditions is weaker but survival and recruitment are not hindered by harsh environmental conditions. However, the degree to which competitive interactions influence temporal fluctuations in richness compared to direct effects of the fluctuating environment probably varies across the productivity gradient of the Great Plains. Although reduction in competitive dominance by a warm-season grass under more variable precipitation conditions was used to explain greater diversity in the precipitation-manipulation experiment in Kansas tallgrass

$\leftarrow$

http://dx.doi.org/10.2111/REM-D-10-00136.s2 are indicated next to each connector, with a symbol showing the character (negative, neutral, positive) of an effect if values were not published (e.g., a positive correlation was reported). ${ }^{*}$ For fire, values are compared to no fire for frequency and to spring fire for season, except study "a," which compared post- to pre-fire. 

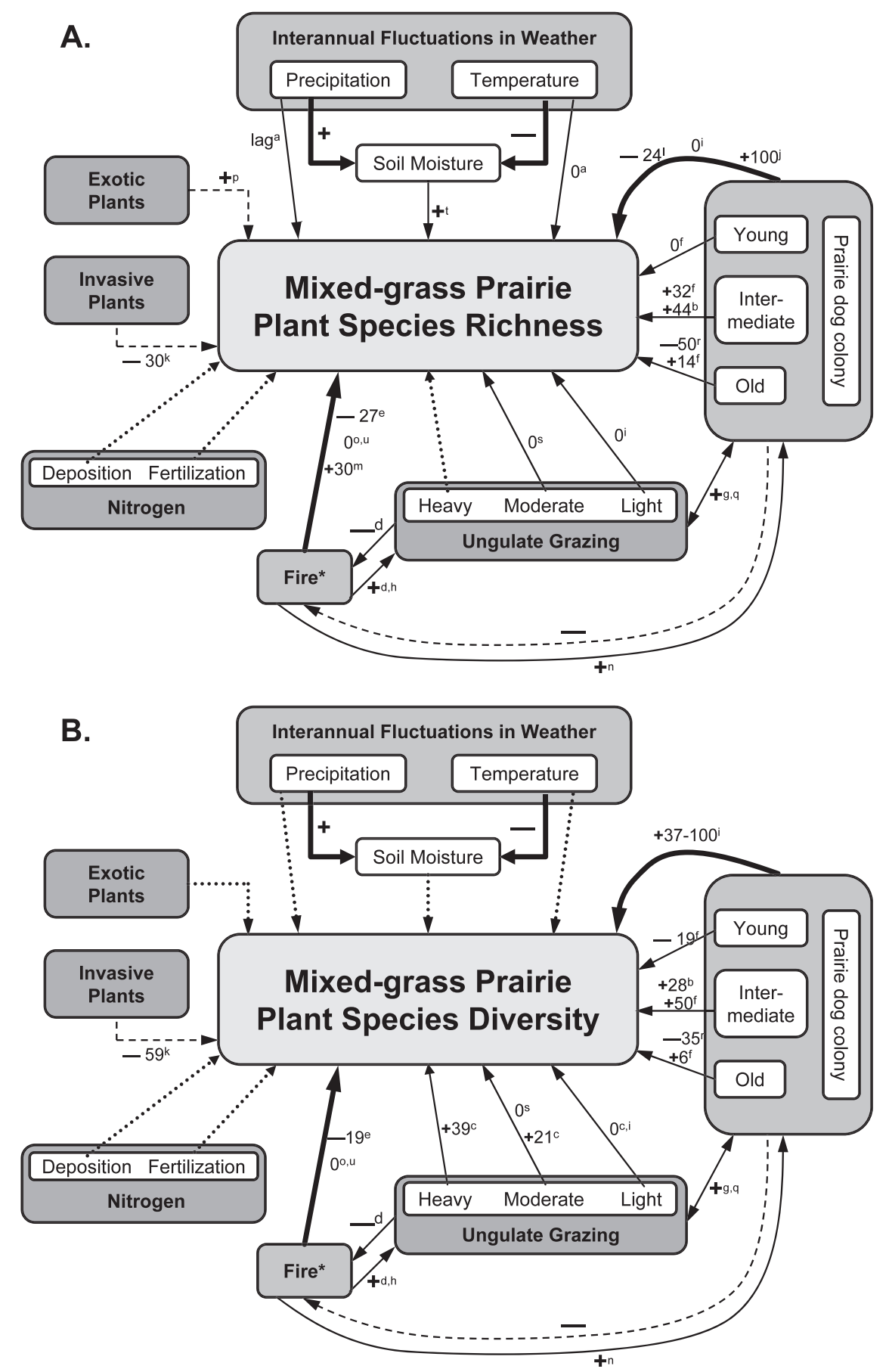

Figure 3. Conceptual diagram summarizing published information on effects of natural and anthropogenic drivers on plant species richness (A) and diversity (B) in medium productivity grasslands (mixed-grass prairie) within the Great Plains region. Notations follow those of Figure 2. ${ }^{*}$ Fire results are compared to no fire.

prairie (Knapp et al. 2002), competition intensity was not related to precipitation or soil moisture in more xeric Canadian mixed-grass prairie, where direct year effects were stronger than competition effects on richness (Wilson 2007). In addition, Laughlin and Moore's assumption that the productivityrichness relationship is unimodal is not well supported. When measured across space, the relationship between productivity and richness at local scales tends to be positive linear or nonexistent (Gillman and Wright 2006; Bai et al. 2007). Finally, theories relating various diversity indices to produc- tivity are nonexistent, but empirical analysis suggests that richness and diversity are not related to productivity in the same way (Chalcraft et al. 2009).

\section{Summary of Climate Effects}

The empirical evidence for temporal relationships between climatic factors and species richness or diversity in GPG is not strong at this time, but it is likely that soil moisture is an integrating factor for these relationships (Figs. 2-4). One study (Adler and Levine 2007) suggests that lag effects in precipita- 

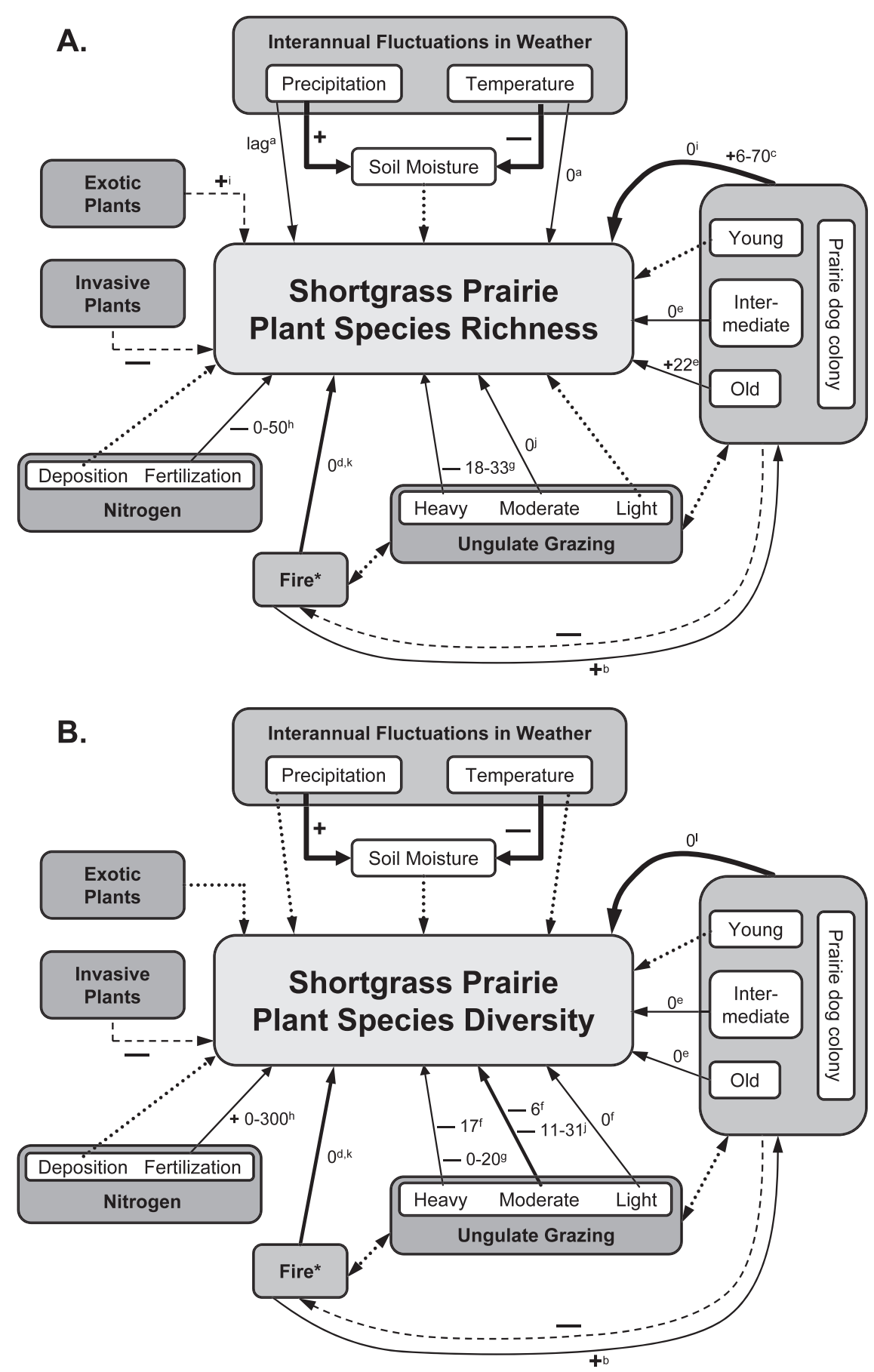

Figure 4. Conceptual diagram summarizing published information on effects of natural and anthropogenic drivers on plant species richness (A) and diversity (B) in low-productivity grasslands (shortgrass prairie) within the Great Plains region. Notations follow those of Figure $2 .{ }^{*}$ Fire results are compared to no fire.

tion affect richness in mixed- and shortgrass prairies, but that temperature is not an important factor (Figs. 3A and 3B). Our own work found a variety of relationships between temperature/ precipitation and richness/diversity depending on location and management practices (J. Jonas et al., unpublished data, 2011). We indicate the lack of data and theory on effects of temperature and precipitation, those driven by both soil moisture and direct effects, in our conceptual models (Figs. 2-4). Clearly, more investigation is needed to understand and predict the effects of precipitation and temperature fluctuations. The growing number of experiments in which both of these variables are manipulated (e.g., Parton et al. 2007) will improve this understanding, as will consistent monitoring of natural fluctuations in both climate and richness/diversity.

\section{BLACK-TAILED PRAIRIE DOG COLONIES}

Black-tailed prairie dogs (Cynomys ludovicianus), the most widespread prairie dog species, are sedentary, colonial rodents. 
In mixed- and shortgrass prairie, they create areas of intense herbivory coupled with ground disturbance (burrowing and mound deposition). They are a controversial topic in GPG because they consume the same vegetation as domestic livestock, thereby reducing the amount of standing plant biomass available for livestock (Kotliar et al. 1999). Often seen as pests, government-sponsored eradication programs and conversion of native prairie to agriculture have resulted in the extirpation of the species from more than $90 \%$ of their historic range (Stapp 1998). Black-tailed prairie dogs continue to be highly managed, either as pests (and therefore eradicated as much as possible) or as keystone species of an ecosystem (and therefore protected).

Colonies can range in size from $<1$ ha to hundreds of hectares. Within colonies, burrows are surrounded by mounds of excavated soil and can be as dense as $275 \mathrm{ha}^{-1}$ (Archer et al. 1987; Cincotta et al. 1989). Prairie dogs also reduce vegetation height either through consumption or clipping to reduce visual barriers for predator detection (Hoogland 1995). This constant pressure on the vegetation causes significant shifts in composition, with a pattern reflecting the amount of time a colony has been active. Early on $(<4 \mathrm{yr})$, taller perennial grasses are largely replaced by short grass species, which are later $(>8 \mathrm{yr})$ replaced by annual and mat-forming perennial forbs; areas occupied the longest are characterized by high coverage of bare ground and forb species highly tolerant of grazing (Coppock et al. 1983; Archer et al. 1987; Cincotta et al. 1989). The length of time in each stage varies with initial composition and perhaps with precipitation conditions.

Although composition changes due to prairie dogs are relatively consistent in mixed-grass prairies, richness and diversity responses are not. In Texas mixed-grass prairie, diversity $\left(\mathrm{H}^{\prime}\right)$ was approximately $35 \%$ lower on a $20+$-yr-old colony than off the colony, and in one of the $2 \mathrm{yr}$ of the study, species richness on colony was half that of off colony (Weltzin et al. 1997). Similarly, in a study where 40 colonies in a Montana mixed-grass prairie ranging in age from $<10 \mathrm{yr}$ to $>50 \mathrm{yr}$ were considered together, species richness was $24 \%$ lower on colony than off (Johnson-Nistler et al. 2004). By contrast, in a South Dakota mixed-grass prairie diversity $\left(\mathrm{H}^{\prime}\right)$ was $37-100 \%$ greater on colony than off, with values depending on the year of data collection; species richness at the $0.25 \mathrm{~m}^{2}$ plot scale did not vary between on and off colony, but the total number of species on colony was twice that off colony (Fahnestock and Detling 2002; Fahnestock et al. 2003). The age of the colonies in these studies was not stated, but in a different South Dakota mixed-grass prairie, two studies found that diversity peaked at intermediate colony ages, though "intermediate" was not consistent between the two studies. In one, diversity $\left(e^{\mathrm{H}^{\prime}}\right)$ was $28 \%$ greater at $2 \mathrm{yr}$ and $3 \mathrm{yr}$ after colony establishment than 4-6 yr after establishment or outside of the colony (Archer et al. 1987). In the other, diversity (H: McArthur's diversity index) and species richness were highest 3-8 yr after colony establishment, second highest in the oldest part of the colony ( $>26 \mathrm{yr}$ ), and lowest at the edge (1-2 yr) or off the colony (Coppock et al. 1983). Richness in the first study was $44 \%$ greater on colony than off, regardless of colony age, but $2 \mathrm{yr}$ of excluding prairie dogs from a 42-yr-old colony in the same area had no effect on either richness or diversity (Cid et al. 1991).
Diversity and richness responses to prairie dogs in shortgrass prairie are also variable. On colonies of undetermined age in northeastern Colorado, the total number of plant species was higher on colony than off, but the difference was much larger on one site ( $70 \%$ higher on vs. off) than another $(6 \%)$ (Bonham and Lerwick 1976). Another study in northeastern Colorado found species richness was $22 \%$ higher on old $(>20 \mathrm{yr}$ ) colonies than off but did not differ between on and off younger (3-7 yr) colonies; diversity $\left(\mathrm{H}^{\prime}\right)$ did not differ between on and off colony of any age (Hartley et al. 2009). In southwestern Kansas and southeastern Colorado, there were no significant differences in either diversity $\left(\mathrm{H}^{\prime}\right)$ or richness between oncolony and random off-colony locations (Winter et al. 2002).

\section{Summary of Prairie Dog Effects}

It has been suggested that the effects of prairie dog colonies on diversity and richness are not consistent between mixed-grass and shortgrass prairies (Stapp 1998). Our results support this statement (Fig. $3 \mathrm{~A}$ vs. $4 \mathrm{~A}, 3 \mathrm{~B}$ vs. $4 \mathrm{~B}$ ) but also show that less information is available for shortgrass areas. Effects were stronger and varied more with colony age in mixed-grass than in shortgrass prairie, with the most positive effects occurring in intermediate-aged colonies in mixed-grass prairies. This illustrates the importance of considering colony age when using this information for management decisions, and when investigating and reporting the effects of prairie dog colonies on plant communities. Equally important is interpreting effects of prairie dog colonies in the proper scale context. Even if richness or diversity are lower on colony compared to off, the substantial differences in composition between the two areas produces greater richness and diversity at the landscape scale.

\section{GRAZING BY LARGE UNGULATES}

Prior to European settlement, GPG were grazed by large herds of free-roaming bison and elk. Except in relatively small and spatially disparate preserves and parks, elk have been eliminated and bison have been widely replaced by domestic cattle (Knapp and Seastedt 1998). The diets of both bison and cattle consist primarily of graminoids, with forbs and browse accounting for a slightly higher proportion of cattle diets than bison diets; cattle also tend to spend more time foraging than do bison (Plumb and Dodd 1993; Hartnett et al. 1997; Steuter and Hidinger 1999). Due to the economic importance of cattle grazing in GPG, large ungulate grazing is probably the moststudied driver of plant assemblage composition in the region. Most of these studies address dominant plant species or functional type abundance, but many also investigate effects of grazing on species richness or diversity.

The effects of grazers on plant assemblages in GPG depend in part on the productivity of a site. Lower productivity sites, such as those on hilltops, with poor soils, or in regions of lower precipitation, are dominated by shorter statured species, while taller statured species, especially warm-season grasses, dominate in higher productivity sites (Knapp and Seastedt 1998). Because shorter species are generally more tolerant of grazing than taller species (Hickman et al. 2004; Milchunas and NoyMeir 2004), low-productivity systems often show less response to grazing than high-productivity systems (Milchunas et al. 
1989, 1998). In the latter, negative effects of grazers on the dominant tallgrass species help facilitate the establishment of subdominant and infrequent species (Collins et al. 2002; Bakker et al. 2003; Hickman et al. 2004).

In the tallgrass region, consumption of the dominant grass species creates opportunities for the establishment of annuals and forbs by increasing water and light availability (Fahnestock and Knapp 1994). These effects account for observed increases in richness, diversity, and species turnover rates associated with grazing (Collins 1987; Collins and Steinauer 1998; Bakker et al. 2003; Towne et al. 2005). In an experimental grazing study in Flint Hills (Kansas) tallgrass prairie, species richness and diversity $\left(\mathrm{H}^{\prime}\right)$ were $20 \%$ and $14 \%$ higher, respectively, in pastures with the highest cattle stocking rate vs. ungrazed pastures and those with low and moderate stocking densities ${ }^{1}$ within one year, and the difference continued through the remaining $5 \mathrm{yr}$ of the study (Hickman et al. 2004). In another Flint Hills study (Hartnett et al. 1996), species richness was $54 \%$ higher in bison-grazed vs. ungrazed lowland sites burned annually, and $41 \%$ higher in sites burned every $4 \mathrm{yr}$; bison grazing also increased species richness in upland sites, but to a lesser degree (19\% in those burned every $4 \mathrm{yr}$, not significantly in annually burned sites). Diversity $\left(\mathrm{H}^{\prime}\right)$ was also consistently higher in grazed sites, but in lowlands the effect was mild $(7 \%$ increase in annually burned areas, not significant in areas burned every $4 \mathrm{yr}$ ) compared to in uplands (34\% and $15 \%$ in annual and 4-yr fire areas, respectively). In a third study in the Flint Hills, sites moderately grazed by bison for $8 \mathrm{yr}$ had $25 \%$ higher species richness than prior to the reintroduction of bison, while similar ungrazed sites experienced a slight decline in species richness during the same period (Bakker et al. 2003). In an experiment comparing the effects of bison and cattle grazing on tallgrass prairie in which animal mass and management did not differ, both richness and diversity $\left(\mathrm{H}^{\prime}\right)$ of the plant assemblages increased after $10 \mathrm{yr}$ of moderate grazing by either species, but the increases were greater in sites grazed by bison (richness $95 \%$, diversity $75 \%$ ) than in those grazed by cattle $(70 \%, 60 \%$; Towne et al. 2005). Although we did not find any studies that investigated the effects of heavy grazing on species richness or diversity in tallgrass prairies, it can lead to the replacement of native grass species with nonnative grasses within just a few years (Weaver and Darland 1948; Kucera 1956). A few native forb and woody species increase with heavy grazing, but most native forbs respond negatively (Weaver and Darland 1948; Kucera 1956; Hickman and Hartnett 2002). These findings suggest that species richness and diversity would likely be lower under heavy grazing.

Most of the dominant grass species in shortgrass prairie and some grasses in the mixed prairie are adapted to tolerate grazing (Milchunas and Lauenroth 1993; Milchunas et al. 2008) via basal meristems, the ability to reproduce vegetatively, and relatively short stature (Milchunas et al. 1988). As a result, most studies for the shortgrass region, whether long or short term, have reported few changes in the grass component of plant communities in response to either low or high grazing intensities, although forbs and shrubs typically have a negative response (Milchunas et al. 1988; Biondini et al. 1998; Manier

\footnotetext{
1Stocking rates for all grazing studies cited are in Table S1, available at http://dx.doi.org/10.2111/ REM-D-10-00136.s1
}

and Hobbs 2006; Milchunas et al. 2008). Although shortgrass species such as Bouteloua gracilis and B. dactyloides increase in response to high grazing intensity in short- and mixed-grass prairies, the abundance and productivity of midheight and tall grass species in these systems are often negatively impacted to the point of loss of these species at a locality (Potvin and Harrison 1984; Hart 2001; Milchunas et al. 2008).

Spiny plant clumps and geologic formations can serve as refuges for grazing-sensitive plants in the shortgrass region, and studies investigating the plant assemblages associated with them provide information on grazing effects in this region (Rebollo et al. 2002; Milchunas and Noy-Meir 2004). In a lightly grazed Colorado shortgrass steppe, diversity $\left(\mathrm{H}^{\prime}\right)$ was $11 \%$ higher in cactus (Opuntia polyacantha) patches than in adjacent noncactus sites, although this was due to decreased dominance of $B$. gracilis inside the clumps rather than a change in species richness (Rebollo et al. 2002). Species richness was $8 \%$ higher in refuges near rocky buttes than in adjacent moderately grazed areas in a Schizachyrium scoparium-dominated, eastern Colorado grassland (Milchunas and Noy-Meir 2004).

These refugia studies and the responses of the native forb species in the short-grass region strongly suggest that grazing generally has a negative effect on species richness and diversity in the less productive part of the GPG. However, direct tests of grazing effects yield mixed results. In one study of Colorado shortgrass prairie, diversity $\left(\mathrm{H}^{\prime}\right)$ was $31 \%$ lower in moderately grazed vs. ungrazed areas, but richness was not affected (Rebollo et al. 2002). In another study in the same region, diversity $\left(e^{\mathrm{H}^{\prime}}\right)$ was approximately $20 \%$ higher under no or light grazing than under heavy grazing after $13 \mathrm{yr}$ (Klipple and Costello 1960 as cited in Milchunas et al. 1998). In the same prairie after $47 \mathrm{yr}$, diversity $\left(\mathrm{H}^{\prime}\right)$ in heavily grazed ridge tops did not differ from ungrazed ridge tops, while in more productive swale locations, heavy grazing led to approximately $15 \%$ lower diversity (Milchunas et al. 1989). In this study, species richness was consistently, though not always significantly, higher in ungrazed vs. heavily grazed sites regardless of topographic position, with the greater differences occurring in a wet vs. a dry year (Milchunas et al. 1989).

In mixed-grass prairie, three studies show generally, but not always, neutral effects of ungulate grazing on richness or diversity. In an Alberta study, diversity $\left(\mathrm{H}^{\prime}\right)$ and richness did not differ between moderately grazed and ungrazed areas after $70 \mathrm{yr}$ (Willms et al. 2002). In a South Dakota study, 3 yr of excluding bison grazing yielded similar results (Fahnestock and Detling 2002). In contrast, in a Saskatchewan study, diversity $\left(\mathrm{H}^{\prime}\right)$ was $21 \%$ and $39 \%$ greater under moderate and heavy grazing, respectively, than in ungrazed exclosures in two sites, but there was no effect of light grazing (Bai et al. 2001).

\section{Summary of Grazing Effects}

Milchunas et al. (1988) hypothesized that in GPG that evolved with large ungulate grazing, diversity should decrease monotonically, but only slightly, with increased grazing intensity in the lower productivity, shortgrass portion of the region, whereas in the higher productivity, tallgrass portion, diversity should be greatest at intermediate grazing intensities. The literature to date generally follows this pattern for richness and for diversity. In higher-productivity GPG, one study showed 
greater richness and diversity at moderate vs. low cattle stocking rates and suggested slightly higher richness and diversity at low stocking rates compared to no grazing (Hickman et al. 2004), one showed neutral to positive effects of light bison grazing on richness and diversity (Hartnett et al. 1996), one showed greater richness with moderate bison stocking compared to an ungrazed control (Bakker et al. 2003), and one showed increases in richness and diversity with moderate cattle or bison grazing compared to the same area before grazing began (Towne et al. 2005). Therefore, a positive effect of moderate grazing on richness and diversity is well supported, but much less information is available for the effects of light grazing and essentially none for heavy grazing in tallgrass GPG (Fig. 2). For shortgrass GPG, we found no studies that showed a positive effect of grazing on richness or diversity. Instead, negative or neutral effects on richness and diversity occurred at moderate and high grazing intensities (Fig. 4). One within-study comparison of different grazing intensities, as well as cross-study comparisons of negative effects (when they occurred) also support the Milchunas et al. (1988) model in that the magnitude of negative effects is generally greater under heavy grazing than under light or moderate grazing (Fig. 4). Grazing effects on diversity and especially richness in mixedgrass prairie have received considerably less attention than in the other prairie types (Fig. 3). The information that is available suggests that the richness and diversity responses of mixed-grass prairie to grazing may be more like that of tallgrass than shortgrass prairie in that no negative effects have been shown. All prairie types would benefit from more research explicitly comparing the effects of the full range of stocking intensities practiced by range managers.

\section{FIRE}

Historically, periodic fire was an integral part of the ecology of GPG ecosystems (Daubenmire 1968), although fire frequency differed among grassland types (Knapp et al. 1998b; Milchunas et al. 1998). The lower-productivity, semiarid, shortgrass systems likely had a lower historical frequency of fires due to a smaller fine fuel load than in the more humid and productive tallgrass systems. Given these differences in productivity and precipitation, the effects of fire on plant assemblages are expected to differ among grassland types. In tallgrass prairie, a fire generally results in a $1-y r$ increase in productivity in all but the driest years (Adams and Anderson 1978; Glenn-Lewin et al. 1990; Knapp et al. 1998a), but longer-term responses vary with fire frequency, season of burning, and topographic position. A recent review of fire studies in mixed- and shortgrass regions showed that the response of grassland productivity to fire is highly variable, but generally neutral or negative (Scheintaub et al. 2009). Although individual studies have attributed varying fire effects in these grasslands to precipitation in the growing season(s) following the fire (Wright and Bailey 1980; Biondini et al. 1989; Shay et al. 2001; Erichsen-Arychuk et al. 2002; Augustine and Milchunas 2009), the review of 13 studies found no precipitation effect on postfire productivity (Scheintaub et al. 2009). These differences in productivity responses to fire reflect differences in the factors that limit growth between the two systems. In the more productive tallgrass prairies where light is usually more limiting than soil moisture, fire removes litter, thereby increasing soil temperatures earlier in the growing season and stimulating productivity (Knapp et al. 1998a), whereas in semiarid mixed and shortgrass prairies where water availability limits production, increased plant stress due to the loss of soil moisture after fire consumes the detrital layer can lead to decreased productivity (Redmann 1978). Regardless of the system, fire effects on grassland plant assemblages are likely influenced by both fire frequency and timing.

In productive tallgrass prairie sites, fire is a common management tool used to increase forage production for livestock (Towne and Kemp 2003, 2008) and to prevent or reduce encroachment by native woody and exotic species. Consequently, many studies have investigated the effects of fire on plant assemblages in this region, but most of them come from one location in the Flint Hills of Kansas, the Konza Prairie Biological Station. At this site, annual spring burning led to species richness decreases ranging from $0 \%$ to $20 \%$, depending on the experiment and the time since initiation of burning (Collins et al. 1998). By contrast, in an Oklahoma tallgrass prairie $3 \mathrm{yr}$ of annual spring fires led to a $14 \%$ increase in species richness but no effect on diversity $\left(e^{\mathrm{H}^{\prime}}\right.$; Collins 1987).

Two studies from the Flint Hills also measured the response of richness or diversity to fire frequency. Species richness was $14-57 \%$ higher on sites burned intermittently (every 3-4 yr) and infrequently $(>10 \mathrm{yr})$ than on those burned annually (Collins et al. 1995; Collins 2000) and declined linearly with increasing fire frequency (Collins et al. 1995). Two other studies in the same system found that species richness was not related to the number of years since fire (Gibson 1988), but diversity $\left(e^{\mathrm{H}^{\prime}}\right)$ increased with time since fire until about $7 \mathrm{yr}$ or $8 \mathrm{yr}$, then either leveled off (lowland soils) or (in upland soils) decreased to levels similar to those immediately following a fire (Gibson and Hulbert 1987).

The effects of burning on tallgrass prairie may also be mediated by the timing of fire. In an Oklahoma prairie, a single late-winter or summer fire yielded similar results: a $34 \%$ decrease in herbaceous species richness but an $8 \%$ increase in herbaceous diversity $\left(e^{\mathrm{H}^{\prime}}\right.$; Adams et al. 1982). After $8 \mathrm{yr}$, species richness did not differ among sites burned annually in spring, autumn, or winter (Towne and Kemp 2003). However, after $14 \mathrm{yr}$, sites burned biennially in the summer had 28\% higher species richness than sites burned annually in the spring, primarily due to an increased number of forb species (Towne and Kemp 2008). In less productive upland areas, diversity $\left(\mathrm{H}^{\prime}\right)$ decreased with repeated spring burning so that it was approximately $60 \%$ of that in autumn- and winter-burned areas after $8 \mathrm{yr}$; in lowlands, diversity decreased with both spring and autumn burning but stayed the same over time with winter burning (Towne and Kemp 2003). In the 14-yr study, diversity responses were similar in the two topographic positions: It increased in areas of biennial summer burning but initially declined then stabilized in spring-burned areas so that it was approximately $75 \%$ of that in summer-burned areas (Towne and Kemp 2008).

Due to the negative or neutral effects of fire on productivity in the mixed-and shortgrass regions of the Great Plains, fire has not been a common management tool in these systems (Wright and Bailey 1980; Augustine and Milchunas 2009; Scheintaub et al. 2009). Consequently, investigations comparing 
effects of different fire frequencies, seasons, or time since fire on species richness and diversity are rare. However, studies from a variety of sites provide some information about the response of these systems to a single fire. In a New Mexico shortgrass prairie with very low forb cover and richness, species richness and diversity $\left(\mathrm{H}^{\prime}\right)$ did not differ significantly among plots burned once in the dormant or growing season or not burned at all (Brockway et al. 2002). In a more diverse Colorado shortgrass prairie, results were the same: no change in richness or diversity $\left(\mathrm{H}^{\prime}\right)$ after one or two spring fires (Scheintaub et al. 2009).

A fall wildfire in Nebraska Sandhills prairie resulted in no change in species richness or diversity $\left(\mathrm{H}^{\prime}\right)$ in the next growing season (Morrison et al. 1986). One and 2 yr after a spring wildfire in the same type of prairie, species richness in grass, grass-like, and woody life-form groups did not change, but forb richness declined 35\% (Wolfe 1973). In Manitoba mixed-grass prairie, small plots were left unburned or were burned in the spring either in the first year only or in both the first and second years of the 2-yr study; diversity $\left(\mathrm{H}^{\prime}\right)$ and richness did not differ among these treatments (Wilson and Shay 1990). In a degraded mixed-grass prairie of east-central North Dakota, species richness was $30 \%$ higher $1 \mathrm{yr}$ after a spring prescribed fire in burned fields than in an adjacent control field (Kirsch and Kruse 1973). In an Oklahoma mixed-grass prairie, a recently burned area had $19 \%$ lower diversity $\left(e^{\mathrm{H}^{\prime}}\right)$ and $27 \%$ lower richness than an unburned area (Collins and Barber 1985). In a mixed-grass prairie of north-central South Dakota, the effects of $3 \mathrm{yr}$ of annual spring burns, biennial summer burns, and annual fall burns were compared to unburned controls, but only forb richness and diversity $\left(\mathrm{H}^{\prime}\right)$ were reported (Biondini et al. 1989). Forb richness differed among treatments only in the first year of the study, when the unburned and summerburned treatments had $\geq 34 \%$ higher richness than in fall- and spring-burned treatments that year or than in all treatments in the following 2 yr. Forb diversity followed a similar pattern but in different years; diversity was approximately 33\% higher in the summer-burned and unburned treatments vs. spring- and fall-burned treatments in the second and third years of the study. The authors of the study note that the fire-induced differences in richness and diversity were within the range of within-treatment year-to-year variation in these metrics, which seemed to be at least partly driven by precipitation. A similar observation has been made based on fire-monitoring data from mixed-grass prairies in northern Great Plains national parks (Wienk et al. 2009).

\section{Summary of Fire Effects}

The standard paradigm for the effect of fire on productive GPG is that diversity and richness decrease with increasing frequency of fires because fire reduces litter and increases light availability to the tillers of dominant grass species, thereby increasing their productivity and competitive suppression of other species (Collins and Steinauer 1998). In less productive grasslands, litter accumulation, and therefore light limitation to standing vegetation and germinating seedlings, is relatively low even in the absence of fire and therefore does not change much when it is burned off. Consequently it has been hypothesized that diversity and richness responses to fire in less productive grasslands will be minimal (Oesterheld et al. 1999; Knops 2006).
All but two of the studies of fire in tallgrass prairie came from one location (Konza Prairie), and most of the information is for richness, not diversity (Fig. 2). Although this location does provide long-term data unavailable in most ecological experiments, the fact that one study from a different location yielded a positive effect of annual fires on richness (Collins 1987), compared to the negative effect in the Flint Hills studies, suggests that wider exploration of fire effects (frequency and timing) on richness and diversity in the tallgrass region is warranted. The studies we found for shortgrass (Fig. 4) prairie had generally consistent results of no significant effect of fire on richness or diversity, which is consistent with theory (Oesterheld et al. 1999; Knops 2006). Mixed-grass prairie fire studies came from a wide variety of locations and had a wide variety of responses (Fig. 3). The short duration (Wilson and Shay 1990; Brockway et al. 2002), lack of control treatments (Collins and Barber 1985; Wienk et al. 2009), and low initial diversity/richness (Wilson and Shay 1990; Brockway et al. 2002) of these studies suggest that more research on fire effects in these systems is also needed, especially controlled experiments comparing the effects of different fire frequencies and seasons.

\section{INTERACTION OF UNGULATE GRAZING, FIRE, AND PRAIRIE DOGS}

The shifting mosaic model of fire-grazing interactions in GPG suggests that positive and negative feedbacks between susceptibility to fire and grazer preferences promotes heterogeneity in the composition and diversity of these grasslands (Hobbs et al. 1991; Fuhlendorf and Engle 2004). Because ungulate grazers are attracted to the higher-quality plant material in recently burned areas (Biondini et al. 1999; Erichsen-Arychuk et al. 2002; Fuhlendorf and Engle 2004), plant biomass accumulates in areas that have not been recently burned. As biomass accumulates in an area over time, the increase in fine fuels causes it to eventually become more prone to wildfire. Once burned, grazers selectively feed in that area, preventing the build-up of fine fuels and decreasing the probability of a recurrent fire in the short term. Grazers will then abandon that area once a more recently burned patch becomes available (Biondini et al. 1999).

Although this shifting mosaic may result in higher plant species richness or diversity at landscape scales, the effect of the interaction of fire and grazing at the $0.25-10 \mathrm{~m}^{2}$ plot level is inconsistent among the three studies we found for tallgrass prairie. Burning increased species richness of an Oklahoma tallgrass prairie by $\sim 11 \%$ regardless of whether it was grazed or not (Collins 1987), but in a Flint Hills (Kansas) study, grazing moderated a negative burning effect: Burning alone reduced species richness by $20 \%$ from the control, and grazing increased richness by about $35 \%$ over the control with or without burning (Collins et al. 1998). In an Iowa Loess Hills study, total species richness was $18 \%$ higher in unburned, grazed areas than in those that were both grazed and burned or only burned. However, this grazing effect was largely due to exotic species; burned only areas had higher native species richness than those that were grazed only or grazed and burned (Brudvig et al. 2007). 
Diversity had a similarly divergent response among these three studies. In the Oklahoma study, diversity $\left(\mathrm{H}^{\prime}\right)$ was $85 \%$ greater in annually burned areas that were also grazed than in those that were not grazed; however, diversity in ungrazed areas was about $60 \%$ higher in unburned than in burned areas (Collins 1987). In the Iowa study, diversity $\left(\mathrm{H}^{\prime}\right)$ did not differ significantly among treatments, but the trend was different than in the Oklahoma study: Burned and grazed areas had diversity intermediate between burned only (lowest diversity) and grazed only (Brudvig et al. 2007). A variety of factors could account for these different responses: lower fire frequency at the Iowa site (1-3 fires in the 7-yr study period vs. annual burning), different grazers (cattle vs. bison), grazing intensities (Table S1), or seasons of grazing are all possibilities.

Although some studies have investigated how short- and mixed-grass prairie plant assemblages in GPG respond to fire in combination with ungulate grazing (e.g., Erichsen-Arychuk et al. 2002; Harris et al. 2008), we found none that reported plant species richness or diversity. Similarly, although prairie dog colonies tend to expand more quickly into burned than unburned areas (Milne-Laux and Sweitzer 2006; Augustine et al. 2007), we found no studies investigating their interactive effects on plant richness and diversity. The effect of the combination of prairie $\operatorname{dog}$ and ungulate grazing has been investigated, however. Although bison and other large ungulates preferentially graze in prairie dog colonies, and the reduced grassland stature caused by ungulate grazing may attract prairie dogs (Detling 1998; Truett et al. 2001), the impact of ungulate grazing on richness and diversity on prairie dog colonies may be minor. In two South Dakota mixed-grass prairies, excluding bison grazing from prairie dog colonies for $2 \mathrm{yr}$ or $3 \mathrm{yr}$ resulted in no changes in plant species richness or diversity $\left(\mathrm{H}^{\prime}\right.$; Cid et al. 1991; Fahnestock and Detling 2002). The similarly minimal response of these metrics to prairie dog exclusion in these studies suggests that $2-3 \mathrm{yr}$ is not enough time for the long-term effects of prairie dogs on vegetation to reverse, however.

\section{Summary of Interaction Effects}

GPG evolved with a variety of disturbance types that rarely occurred alone, but current management practices often separate them. Evidence so far accumulated, though somewhat sparse, suggests that the interactions of some of these disturbances affect plant richness and diversity in complicated ways. Interactive effects of ungulate grazing and fire on plant species richness and diversity in tallgrass prairie are so far inconsistent, whereas they are unstudied in mixed- and shortgrass prairie. The effects of prairie dog colonies on mixed-grass richness and diversity may overwhelm any additional effects of ungulate grazing or fire, though the latter is untested, as are interactive effects of ungulates and prairie dogs in shortgrass prairie. We indicated the potential for these interactions to affect richness and diversity, as well as the present sparseness of consistency or information, in our models (Figs. 2-4).

\section{NITROGEN FERTILIZATION}

Nitrogen (N) is often a limiting factor for plant growth in GPG (Wright 1976; Tilman 1987; Seastedt et al. 1991), but it becomes less limiting as water becomes more limiting in the western portion of the Great Plains (Gough et al. 2000; McCulley et al. 2009). Under ambient conditions, species richness has been shown to be positively related, although weakly, to soil $\mathrm{N}$ pools in tallgrass prairie (Bakker et al. 2003). This may be the case in shortgrass prairie as well, since both total soil $\mathrm{N}$ and species diversity tend to be lowest in the presence of B. gracilis (Milchunas et al. 2008).

The addition of $\mathrm{N}$ fertilizers to GPG ecosystems is typically associated with an overall increase in productivity and a decrease in species richness and diversity (Lorenz and Rogler 1972; Collins and Steinauer 1998; Gough et al. 2000; Suding et al. 2005; Clark et al. 2007), but the magnitude of these impacts varies widely. $\mathrm{N}$ fertilization led to a $30-60 \%$ decline in species richness in Flint Hills tallgrass prairie depending on whether the prairie was burned or not (Collins and Steinauer 1998), and in a Minnesota tallgrass sand prairie/savanna, species richness was $35-50 \%$ lower with $\mathrm{N}$ fertilization depending on the year (Tilman 1993). By contrast, in a shortgrass prairie, $\mathrm{N}$ fertilization alone resulted in no change in richness or diversity, but when combined with water addition, $\mathrm{N}$ fertilization approximately tripled diversity $\left(e^{\mathrm{H}^{\prime}}\right)$ but halved species richness (Milchunas et al. 1990).

Nitrogen fertilization effects on GPG are modified by other management activities. Fire and $\mathrm{N}$ fertilization have been shown to have additive effects on plant assemblages in Flint Hills tallgrass prairie, where there was an approximately $65 \%$ increase in total biomass after $4 \mathrm{yr}$ of $\mathrm{N}$ fertilization in sites that were annually burned, compared to only a $20 \%$ increase in biomass due to fertilization on areas that were not burned (Seastedt et al. 1991). In this study, forb biomass in annually burned and fertilized plots increased $125 \%$ compared to annually burned, unfertilized plots and nearly $225 \%$ in fertilized compared to unfertilized plots that had not been burned for $4 \mathrm{yr}$. Consequently, it might be surmised that $\mathrm{N}$ fertilization would positively impact species richness or diversity in burned areas, particularly those that are infrequently burned. This was not the case in another study at the same site, however, in which forb biomass and species richness response to $\mathrm{N}$ fertilization in annually burned plots was extremely negative, with the burned and fertilized areas having less than one-third the forb species richness, and less than half the total species richness, as burned areas (Collins et al. 1998).

Although $\mathrm{N}$ fertilization, alone or with other disturbances or management activities, clearly affects plant production, composition, and species richness and diversity in GPG, the results of the studies described above must be taken in the proper context. Almost all of these studies have either been relatively short-term or experimentally applied $\mathrm{N}$ at rates (10$20 \mathrm{~g} \cdot \mathrm{m}^{-2} \cdot \mathrm{yr}^{-1}$ ) more relevant to agricultural fertilization than to atmospheric deposition expected from air pollution $\left(<1 \mathrm{~g} \cdot \mathrm{m}^{-2} \cdot \mathrm{yr}^{-1}\right)$. The effects of $\mathrm{N}$ addition at the latter rates on grassland plant assemblages are less understood. Long-term experiments conducted in native and restored northern tallgrass sand prairies to assess the effects of $\mathrm{N}$ fertilization over a range of application rates found that after nearly $25 \mathrm{yr}$ of fertilization there was a nonlinear relationship between $\mathrm{N}$ fertilization rate and species loss (Clark and Tilman 2008). Although it took more than 5 yr before the negative effects of low-level $\mathrm{N}$ fertilization $\left(1 \mathrm{~g} \cdot \mathrm{m}^{-2} \cdot \mathrm{yr}^{-1}\right)$ on species richness were detected, the overall rate of species loss at this low level was greater than 
under high $\mathrm{N}$ addition rates (Clark and Tilman 2008). These findings suggest that the use of short-term, high- $\mathrm{N}$ fertilization experiments to predict changes in plant assemblages due to chronic atmospheric $\mathrm{N}$ deposition will likely underestimate its negative impacts.

\section{Summary of Nitrogen Addition Effects}

Nitrogen may be added purposely to grasslands as fertilizer in order to increase productivity and nutrient content of forage for domestic grazers. This practice is not widespread in GPG, but widespread low-level $\mathrm{N}$ fertilization may also occur through atmospheric deposition. A continent-wide meta-analysis of nitrogen fertilization experiments found that species loss ranged from $0 \%$ to $65 \%$ when $\mathrm{N}$ was added, but there was no link between fertilization-induced species loss and plant productivity (Clark et al. 2007). Sharp decreases in richness in response to high rates of $\mathrm{N}$ fertilization in two tallgrass prairie studies (Fig. 2A) are consistent with the results from this metaanalysis, which incorporates many ecosystems, but the lack of response (or divergent responses between richness and diversity when combined with water addition; Fig. $4 \mathrm{~A}$ vs. $4 \mathrm{~B}$ ) in a shortgrass prairie study is not. We found no studies investigating the effects of either $\mathrm{N}$ fertilization or lower-level deposition on mixed-grass prairie richness and diversity (Fig. 3). With N deposition from coal-fired power plants expected to increase in the GPG, particularly in the western portion, further research on the effects of low-level $\mathrm{N}$ fertilization on these systems is warranted.

\section{EXOTIC PLANT SPECIES}

Exotic plant species can have both positive and negative effects on species richness and diversity. On the one hand, some exotics become naturalized but minor parts of an ecosystem, thereby adding to richness and perhaps diversity with little or no impact on native species. For example, some studies have shown a positive correlation between native and exotic species richness in GPG (Smith and Knapp 1999; Cleland et al. 2004). On the other hand, other studies have found a negative correlation or a variety of relationships (including none at all), depending on the scale of measurement and location (e.g., Stohlgren et al. 1999; Cully et al. 2003; Guo and Symstad 2008), between native and exotic richness.

A negative correlation may indicate a direct, negative impact (e.g., competitive exclusion) of exotic species on the native assemblage, or it may result from a disturbance that concurrently harms natives and provides colonization opportunities and favorable growing conditions for exotics (MacDougall and Turkington 2005). Distinguishing between these two causes is difficult, and they may occur simultaneously. Perhaps because of this, we found no GPG studies that clearly showed the effect of an exotic plant species on richness or diversity independent of disturbance effects. For example, in mixed-grass prairie/woodland in central Texas, plots containing Bothriochloa ischaemum, an invasive exotic perennial grass, had about $67 \%$ of the richness and $45 \%$ of the diversity $\left(\mathrm{H}^{\prime}\right)$ of those in which B. ischaemum was absent (Gabbard and Fowler 2007). Grazing intensity and prescribed fire had no effect on the distribution of $B$. ischaemum, but the species was more common along roadsides, suggesting that competitive exclusion can occur in undisturbed areas, but that an indirect effect of roadside disturbance might also have occurred.

A recent meta-analysis showed that plant community species richness is generally not saturated regardless of nutrient or water availability (Myers and Harms 2009). Consequently, the incursion of noninvasive exotic plant species should theoretically increase species richness (Figs. 2A, 3A, 4A), but the effect on diversity is unknown (Figs. 2B, 3B, 4B). The effect of a given invasive plant species on richness and diversity is intuitively negative, but clear evidence to support this intuition in GPG is lacking (Figs. 2-4). This lack of evidence may be a moot point for our purposes, however, if an invasive species essentially by definition degrades rangeland condition because it displaces desirable species.

\section{RICHNESS VS. DIVERSITY}

Of the 24 studies we found that reported both richness and diversity responses to a given driver, the direction of the response differed between richness and diversity in 10 of them. When the direction was the same, magnitudes were often quite different, but the different scales on which richness and diversity are measured make this comparison complicated. There was no consistency across studies as to which metric was more responsive (Figs. 2A, 3A, 4A vs. 2B, 3B, 4B). Responses of richness and diversity to drivers reflect different types of changes in the plant community. If a driver causes the loss of only relatively rare species, richness would decline with little effect on diversity. In contrast, if a driver causes significant shifts in the way resources are partitioned among species, diversity may change substantially with little change in richness because of changes in evenness or its inverse, dominance. Although diversity indices, which combine richness and evenness, tend to be more commonly reported, changes in evenness or dominance indices may be more easily interpreted, especially since different diversity indices vary in their sensitivity to richness vs. dominance (Magurran 2004). Because substantial changes in the abundance of key dominant species are often captured in the biotic integrity measurements currently used in rangeland health evaluation (e.g., comparisons to the historical climax plant community; USDA-NRCS 1997), a measurement of diversity (or evenness) may not contribute as much additional information about the condition of a rangeland as would a measurement of species richness. Because data collection for the latter is slightly less time intensive, more in-depth investigation of the implications of the changes in each type of metric for rangeland health are needed to evaluate their relative merits.

The sensitivity of the metric to measurement errors is also important. Species richness is insensitive to observer bias in cover estimates or cover classification systems, whereas diversity is less sensitive to the problem of observers missing rare species. Species-area curves are often recommended as the ideal indicator of biodiversity because they minimize complications of comparisons across studies with different sample unit sizes (Magurran 2004; de Bello et al. 2010). Until many more studies report the relationship between species-area curves and the drivers of interest, however, the more commonly reported 
richness and diversity are more likely to be useful for linking biodiversity to management actions and environmental factors.

\section{IS HIGHER BETTER?}

Relating plant species richness or diversity to rangeland health also begs the question of whether higher values of these metrics are always better. Exotic species may temporarily increase total richness or diversity, but high exotic diversity may ultimately lead to a crash in native richness and abundance (Guo and Symstad 2008). However, most of the studies we found for GPG did not distinguish between exotic and native species when measuring richness and diversity. In those that did, the effect of the driver on total vs. exotic species richness and diversity varied. In Kansas and Iowa tallgrass prairies, burning negatively influenced the frequency, cover, and species richness of exotic plant species (Gibson et al. 1993; Smith and Knapp 1999; Brudvig et al. 2007). In the Kansas studies (Gibson et al. 1993; Smith and Knapp 1999), exotic and native species richness responded similarly to the disturbance, so that total and native richness were lower in more frequently burned areas. In another study, greater richness and diversity $\left(\mathrm{H}^{\prime}\right)$ at higher cattle stocking densities in Kansas tallgrass prairie were not due to exotic species (Hickman et al. 2004). In shortgrass prairie, total richness remained the same, but exotic species richness declined by about $70 \%$ in grazed vs. ungrazed areas (Milchunas et al. 1990, 2008). Clearly, if exotic species are by definition indicators of lower rangeland condition, then richness and diversity indicators should be distinguishing between native and exotic species.

Also, although greater ecosystem functioning is linked with higher richness or diversity in the studies described in the Introduction, there are other situations where greater richness or diversity may indicate a decline in rangeland condition. For example, high-quality tallgrass prairie is characterized by high dominance and low evenness. In this system, increases in diversity and richness occur when very low fire frequency leads to increased abundance of shrubs and trees and to a shift from a grassland to a shrubland state (Abrams and Hulbert 1987; Gibson and Hulbert 1987; Smith and Knapp 1999; Collins 2000). Increases in richness or diversity may also indicate incursions of weedy, ruderal species in response to a disturbance. One study (Bai et al. 2001) explicitly investigated the relationship between plant species richness and diversity and range condition, where range condition was assessed using a standard method of comparing species' abundance distributions against a high-quality standard ("climax"; USDA-NRCS 1997). In this study, diversity $\left(\mathrm{H}^{\prime}\right)$ was greatest in sites scored as "good" condition, compared to "fair" and "excellent"; species richness was not related to range condition at all (Bai et al. 2001). More studies like this one would provide data for critical evaluation of the definition of range condition in the context of plant richness and diversity and vice versa.

\section{IMPLICATIONS}

An ideal indicator of rangeland health would have 1) clear, documented, empirical evidence of how it is affected by important management practices or anthropogenic stressors, 2) sufficiently low natural variability that changes in its condition could be easily detected, and 3) known ranges of acceptable and unacceptable conditions, as well as values that indicate when the crossover from one to the other is being approached (Jackson et al. 2000; Andreasen et al. 2001). All of these provide managers with the information necessary to interpret changes in that indicator and respond with appropriate actions.

Based on the published information that we found, plant species richness or diversity do not yet meet all these criteria. Specifically, for the first criterion, data from enough independent studies, in a range of high to low productivity locations, are needed so that formal meta-analyses can be done to evaluate the effects of the management practices and drivers. Currently, however, even the vote-counting method of synthesizing the results of multiple studies is possible for only a few of the drivers that affect plant richness and diversity in GPG. Consequently, it is difficult to determine the reasons behind discrepancies in results (soil types, climate, initial composition/ diversity, etc.). Similarly, for the second criterion, there are substantial fluctuations in richness and diversity through time even when management practices are held relatively constant. The magnitude of these fluctuations may reflect the method by which the presence and abundance of individual species are measured. Richness measured with intercept (point or line) methods are more susceptible to changes in plant size than are fixed-plot methods, as are diversity measurements calculated from relative cover or biomass compared to those calculated from relative density or numbers of individuals. Although the effect of weather-to which these fluctuations in richness and diversity through time are most often attributed-has been demonstrated in a few studies, more information is necessary to determine the universality of these results. Although we did not address the third criterion, we think it would be difficult to determine critical values of these metrics until at least the first criterion is met. Also, critical values must be determined in a social, not just ecological, context (Martin et al. 2009).

Despite these issues, we do not feel that plant species richness and diversity should continue to be neglected as indicators of rangeland health. After all, how many ecological indicators fully meet these criteria? Also, these metrics do meet other criteria of useful indicators, such as being applicable in all rangeland types and readily measured (Whitford et al. 1998). Finally, as rangelands become increasingly important in the maintenance of biodiversity and the ecosystem services it influences in the Great Plains (Toombs et al. 2010), solid data on trends in plant species richness and diversity will be needed. It is worth noting that a large number of the studies cited in this review come from three Long-Term Ecological Research stations: Konza Prairie, Shortgrass Steppe, and Cedar Creek. The information they provide is invaluable, but similar studies in a broader range of locations are necessary to test the universality of the results derived from these sites; the development of new programs, including the National Ecological Observatory Network (NEON), the National Park Service's Inventory and Monitoring Program, and the Bureau of Land Management's Assessment, Inventory, and Monitoring Strategy in the United States, may help fill this need. Although more information on the responses of plant species richness and 
diversity to management practices and environmental drivers is needed, future work will help fill current gaps, particularly the sensitivity of these metrics to atmospheric $\mathrm{N}$ deposition, warming temperatures, and other drivers becoming more prevalent influences on rangeland ecosystems.

\section{ACKNOWLEDGMENTS}

We thank Gene Towne, Daniel Milchunas, David Hartnett, and two anonymous reviewers for providing helpful comments that greatly improved this manuscript. Emily Nicholas provided valuable assistance compiling literature during the early stages this project, and Betty Euliss compiled Figure 1B.

\section{LITERATURE CITED}

Abrams, M. D., and L. C. Hulbert. 1987. Effect of topographic position and fire on species composition in tallgrass prairie in northeast Kansas. American Midland Naturalist 117:442-445.

Adams, B. W., R. Ehlert, D. Moisey, and R. L. McNell. 2003. Rangeland plant communities and range health assessment guidelines for the Foothills Fescue natural subregion of Alberta. Lethbridge, AB, Canada: Rangeland Management Branch, Public Lands Division, Alberta Sustainable Resource Development, Publication No. T/038. $85 \mathrm{p}$.

Adams, D. E., and R. C. Anderson. 1978. The response of a central Oklahoma grassland to burning. Southwestern Naturalist 23:623-631.

Adams, D. E., R. C. Anderson, and S. L. Coluins. 1982. Differential response of woody and herbaceous species to summer and winter burning in an Oklahoma grassland. Southwestern Naturalist 27:55-61.

Adler, P. B., and J. HilleRislambers. 2008. The influence of climate and species composition on the population dynamics of ten prairie forbs. Ecology 89:3049-3060.

Adler, P. B., And J. M. Levine. 2007. Contrasting relationships between precipitation and species richness in space and time. Oikos 116:221-232.

Alward, R. D., J. K. Detling, and D. G. Milchunas. 1999. Grassland vegetation changes and nocturnal global warming. Science 283:229-231.

Anderson, R. C. 2006. Evolution and origin of the Central Grassland of North America: climate, fire, and mammalian grazers. Journal of the Torrey Botanical Society 133:626-647.

Andreasen, J. K., R. V. O'Neill, R. Noss, and N. C. Slosser. 2001. Considerations for the development of a terrestrial index of ecological integrity. Ecological Indicators 1:21-35.

Archer, S., M. G. Garrett, and J. K. Detling. 1987. Rates of vegetation change associated with prairie dog (Cynomys ludovicianus) grazing in North American mixed-grass prairie. Vegetatio 72:159-166.

Archer, S., And F. E. Smeins. 1991. Ecosystem-level processes. In: R. K. Heitschmidt and J. W. Stuth [EDS.]. Grazing management: an ecological perspective. Portland, OR, USA: Timber Press. p. 109-139.

Augustine, D. J., J. F. Cully, and T. L. Johnson. 2007. Influence of fire on blacktailed prairie dog colony expansion in the shortgrass steppe. Rangeland Ecology \& Management 60:538-542.

Augustine, D. J., and D. G. Milchunas. 2009. Vegetation responses to prescribed burning of grazed shortgrass steppe. Rangeland Ecology \& Management 62:89-97.

Axelrod, D. I. 1985. Rise of the grassland biome, central North America. Botanical Review 51:163-201.

Bal, Y., Z. Abougendia, and R. E. Redmann. 2001. Relationship between plant species diversity and grassland condition. Journal of Range Management 54:177-183.

Bal, Y., J. Wu, Q. Pan, J. Huang, Q. Wang, F. LI, A. Buyantuyev, and X. Han. 2007. Positive linear relationship between productivity and diversity: evidence from the Eurasian Steppe. Journal of Applied Ecology 44:1023-1034.
BaKker, C., J. M. BlaiR, And A. K. Knapp. 2003. Does resource availability, resource heterogeneity or species turnover mediate changes in plant species richness in grazed grasslands? Oecologia 137:385.

Balvanera, P., A. B. Pfisterer, N. Buchmann, J.-S. He, T. Nakashizuka, D. Raffaelli, and B. Schmid. 2006. Quantifying the evidence for biodiversity effects on ecosystem functioning and services. Ecology Letters 9:1146-1156.

Biondini, M. E., B. D. Patton, and P. E. Nrren. 1998. Grazing intensity and ecosystem processes in a northern mixed-grass prairie, USA. Ecological Applications 8:469-479.

Biondini, M. E., A. A. Steuter, and C. E. Grygiel. 1989. Seasonal fire effects on the diversity patterns, spatial distribution and community structure of forbs in the Northern Mixed Prairie, USA. Vegetatio 85:21-31.

Biondini, M. E., A. A. Steuter, and R. G. Hamilton. 1999. Bison use of fire-managed remnant prairies. Journal of Range Management 52:454-461.

Bonham, C. D., And A. LeRwick. 1976. Vegetation changes induced by prairie dogs on shortgrass range. Journal of Range Management 29:221-225.

BorcheRT, J. R. 1950. The climate of the central North American grassland. Annals of the Association of American Geographers 40:1-39.

Branson, D. H., AND G. A. Sword. 2009. Grasshopper herbivory affects native plant diversity and abundance in a grassland dominated by the exotic grass Agropyron cristatum. Restoration Ecology 17:89-96.

Briske, D. D., S. D. Fuhlendorf, and F. E. Smeins. 2006. A unified framework for assessment and application of ecological thresholds. Rangeland Ecology \& Management 59:225-236.

Brockway, D. G., R. G. Gatewood, and R. B. Paris. 2002. Restoring fire as an ecological process in shortgrass prairie ecosystems: initial effects of prescribed burning during the dormant and growing seasons. Journal of Environmental Management 65:135-152.

Brudvig, L. A., C. M. Mabry, J. R. Miller, and T. A. Walker. 2007. Evaluation of central North American prairie management based on species diversity, life form, and individual species metrics. Conservation Biology 21:864-874.

Cardinale, B. J., D. S. Srivastava, J. E. Duffy, J. P. Wright, A. Downing, M. Sankaran, AND C. Jouseau. 2006. Effects of biodiversity on the functioning of trophic groups and ecosystems. Nature 443:989-992.

Cardinale, B. J., J. P. Wright, M. W. Cadotte, I. T. Carroll, A. Hector, D. S. Silvastava, M. Loreau, and J. J. Weis. 2007. Impacts of plant diversity on biomass production increase through time because of species complementarity. Proceedings of the National Academy of Sciences (USA) 104:1812318128.

Chalcraft, D. R., B. J. Wilsey, C. Bowles, and M. R. Willig. 2009. The relationship between productivity and multiple aspects of biodiversity in six grassland communities. Biodiversity and Conservation 18:91-104.

Christensen, J. H., B. Hewitson, A. Busuioc, A. Chen, X. Gao, I. Held, R. Jones, R. K. Kolli, W.-T. Kwon, R. Laprise, V. Magana Rueda, L. Mearns, C. G. Menendez, J. Raisanen, A. Rinke, A. Sarr, and P. Whetton. 2007. Regional climate projections. In: S. Solomon, D. Qin, M. Manning, Z. Chen, M. Marquis, K. B. Averyt, M. Tignor, and H. L. Miller [EDs.]. Climate change 2007: the physical science basis. Contribution of Working Group I to the Fourth Assessment Report of the Intergovernmental Panel on Climate Change. Cambridge, United Kingdom, and New York, NY, USA: Cambridge University Press. p. 847-940.

Cid, M. S., J. K. Detling, A. D. Whicker, and M. A. Brizuela. 1991. Vegetational responses of a mixed-grass prairie site following exclusion of prairie dogs and bison. Journal of Range Management 44:100-105.

Cincotta, R. P., D. W. Uresk, and R. M. Hansen. 1989. Plant compositional change in a colony of black-tailed prairie dogs in South Dakota. In: A. J. Bjugstad, D. W. Uresk, and R. H. Hamre [EDS.]. Proceedings of the Ninth Great Plains Wildlife Damage Control Workshop; 17-20 April 1989; Fort Collins, CO, USA. Fort Collins, C0, USA: US Department of Agriculture, Forest Service, Rocky Mountain Forest and Range Experiment Station, General Technical Report RM-171. p. 171-177.

Clark, C. M., E. E. Cleland, S. L. Collins, J. E. Fargione, L. Gough, K. L. Gross, S. C. Pennings, K. N. Suding, and J. B. Grace. 2007. Environmental and plant community determinants of species loss following nitrogen enrichment. Ecology Letters 10:596-607. 
Clark, C. M., and D. Tilman. 2008. Loss of plant species after chronic low-level nitrogen deposition to prairie grasslands. Nature 451:712-715.

Cleland, E. E., M. D. Smith, S. J. Andelman, C. Bowles, K. M. Carney, M. C. HornerDevine, J. M. Drake, S. M. Emery, J. M. Gramling, and D. B. Vandermast. 2004. Invasion in space and time: non-native species richness and relative abundance respond to interannual variation in productivity and diversity. Ecology Letters 7:947-957.

Coluıs, S. L. 1987. Interaction of disturbances in tallgrass prairie: a field experiment. Ecology 68:1243-1250.

ColuIns, S. L. 2000. Disturbance frequency and community stability in native tallgrass prairie. American Naturalist 155:311-325.

Collins, S. L., and S. C. Barber. 1985. Effects of disturbance on diversity in mixedgrass prairie. Vegetatio 64:87-94.

Collins, S. L., S. M. Glenn, And J. M. Briggs. 2002. Effect of local and regional processes on plant species richness in tallgrass prairie. Oikos 99:571-579.

Collins, S. L., S. M. Glenn, And D. J. Gibson. 1995. Experimental analysis of intermediate disturbance and initial floristic composition: decoupling cause and effect. Ecology 76:486-492.

Collins, S. L., A. K. Knapp, J. M. Briggs, J. M. Blair, and E. M. Steinauer. 1998. Modulation of diversity by grazing and mowing in native tallgrass prairie. Science 280:745-747.

Collins, S. L., and E. M. Steinauer. 1998. Disturbance, diversity, and species interactions in tallgrass prairie. In: A. K. Knapp, J. M. Briggs, D. C. Hartnett, and S. L. Collins [EDS.]. Grassland dynamics: long-term ecological research in tallgrass prairie. New York, NY, USA: Oxford University Press. p. 140-156.

Coppedge, B. R., D. M. Engle, C. S. Toepfer, and J. H. Shaw. 1998. Effects of seasonal fire, bison grazing and climatic variation on tallgrass prairie vegetation. Plant Ecology 139:235-246.

Coppock, D. L., J. K. Detulng, J. E. Ellis, And M. I. Dyer. 1983. Plant-herbivore interactions in a North American mixed-grass prairie. I. Effects of black-tailed prairie dogs on intraseasonal aboveground plant biomass and nutrient dynamics and plant species diversity. Oecologia 56:1-9.

Costanza, R. 1992. Toward an operational definition of ecosystem health. In: R. Costanza, B. G. Norton, and B. Hakell [EDs.]. Ecosystem health: new goals for environmental management. Washington, DC, USA: Island Press. p. 239-256.

Cully, A. C., J. F. Cully, And R. D. Hiebert. 2003. Invasion of exotic plant species in tallgrass prairie fragments. Conservation Biology 17:990-998.

Daubenmire, R. 1968. Ecology of fire in grasslands. Advances in Ecological Research 5:209-266.

de Bello, F., S. Lavorel, P. Gerhold, Ü. Reier, and M. Pärtel. 2010. A biodiversity monitoring framework for practical conservation of grasslands and shrublands. Biological Conservation 143:9-17.

DetLing, J. K. 1998. Mammalian herbivores: ecosystem-level effects in two grassland national parks. Wildlife Society Bulletin 26:438-448.

DufFY, J. E. 2009. Why biodiversity is important to the functioning of real-world ecosystems. Frontiers in Ecology and the Environment 7:437-444.

Erichsen-Arychuk, C., E. W. Bork, and A. W. Bailey. 2002. Northern dry mixed prairie responses to summer wildfire and drought. Journal of Range Management 55:164-170.

FAhnestock, J. T., AND J. K. DetLIng. 2002. Bison-prairie dog-plant interactions in a North American mixed-grass prairie. Oecologia 132:86-95.

Fahnestock, J. T., And A. K. Knapp. 1994. Plant responses to selective grazing by bison: interactions between light, herbivory and water stress. Vegetatio 115:123-131.

Fahnestock, J. T., D. L. Larson, G. E. Plumb, and J. K. Detling. 2003. Effects of ungulates and prairie dogs on seed banks and vegetation in a North American mixed-grass prairie. Plant Ecology 167:255-268.

Fancy, S. G., J. E. Gross, and S. L. Carter. 2009. Monitoring the condition of natural resources in US national parks. Environmental Monitoring and Assessment 151:161-174

Fargione, J., D. Tilman, R. Dybzinski, J. H. R. Lambers, C. Clark, W. S. Harpole, J. M. H. Knops, P. B. Reich, and M. Loreau. 2007. From selection to complementarity: shifts in the causes of biodiversity-productivity relationships in a long-term biodiversity experiment. Proceedings of the Royal Society BBiological Sciences 274:871-876.
Flather, C. H., and C. H. Sieg. 2000. Applicability of Montreal Process Criterion 1conservation of biological diversity-to rangeland sustainability. International Journal of Sustainable Development and World Ecology 7:81-96.

FuHLendoRF, S. D., AND D. M. Engle. 2004. Application of the fire-grazing interaction to restore a shifting mosaic on tallgrass prairie. Journal of Applied Ecology 41:604-614

GabBaRd, B. L., AND N. L. Fowler. 2007. Wide ecological amplitude of a diversityreducing invasive grass. Biological Invasions 9:149-160.

GIBSON, D. J. 1988. Regeneration and fluctuation of tallgrass prairie vegetation in response to burning frequency. Bulletin of the Torrey Botanical Club 115:1-12.

Gibson, D. J., AND L. C. HuLBeRT. 1987. Effects of fire, topography and year-to-year climatic variation on species composition in tallgrass prairie. Vegetatio 72:175-185

Gibson, D. J., T. R. Seastedt, and J. M. Briggs. 1993. Management practices in tallgrass prairie: large- and small-scale experimental effects on species composition. Journal of Applied Ecology 30:247-255.

Gillman, L. N., AND S. D. WRIGHT. 2006. The influence of productivity on the species richness of plants: a critical assessment. Ecology 87:1234-1243.

Glenn-Lewin, D. C., L. A. Johnson, T. W. Jurik, A. Akey, M. Leoschke, and T. Rosburg. 1990. Fire in central North American grasslands: vegetative reproduction, seed germination, and seedling establishment. In: S. L. Collins and L. L. Wallace [EDS.]. Fire in the North American tallgrass prairie. Norman, OK, USA: University of Oklahoma Press. p. 28-45.

Gough, L., C. W. Osenberg, K. L. Gross, and S. L. Collins. 2000. Fertilization effects on species density and primary productivity in herbaceous plant communities. Oikos 89:428-439.

Guo, Q., And A. SymStad. 2008. A two-part measure of degree of invasion for crosscommunity comparisons. Conservation Biology 22:666-672.

Harris, W. N., T. W. Boutton, and R. J. Ansley. 2008. Plant community and soil microbial carbon and nitrogen responses to fire and clipping in a southern mixed grassland. Rangeland Ecology \& Management 61:580-587.

HART, R. H. 2001. Plant biodiversity on shortgrass steppe after 55 years of zero, light, moderate, or heavy cattle grazing. Plant Ecology 155:111-118.

Hartley, L. M., J. K. Detling, and L. T. Savage. 2009. Introduced plague lessens the effects of an herbivorous rodent on grassland vegetation. Journal of Applied Ecology 46:861-869.

Hartnett, D. C., K. R. Hickman, and L. E. Fisher Walter. 1996. Effects of bison grazing, fire, and topography on floristic diversity in tallgrass prairie. Journal of Range Management 49:413-420.

Hartnett, D. C., A. A. Steuter, and K. R. Hickman. 1997. Comparative ecology of native and introduced ungulates. In: F. L. Knopf and F. B. Sampson [EDS.]. Ecology and conservation of Great Plains vertebrates. New York, NY, USA: Springer. p. 72-101.

Hartnett, D. C., and G. W. T. Wilson. 2002. The role of mycorrhizas in plant community structure and dynamics: lessons from grasslands. Plant and Soil 244:319-331.

Hector, A., and R. BAgCHI. 2007. Biodiversity and ecosystem multifunctionality. Nature 448:188-191.

Hector, A., Y. Hautier, P. Saner, L. Wacker, R. Bagchi, J. Joshi, M. Scherer-Lorenzen, E. M. Spehn, E. Bazeley-White, M. Weilenmann, M. C. Caldeira, P. G. Dimitrakopoulos, J. A. Finn, K. Huss-Dannell, A. Jumpronen, C. P. H. Mulder, C. Palmborg, J. S. Pereira, A. S. D. Siamantziouras, A. C. Terry, A. Y. Troumbis, B. Schmid, and M. Loreau. 2010. General stabilizing effects of plant diversity on grassland productivity through population asynchrony and overyielding. Ecology 91:2213-2220.

Hickman, K. R., and D. C. HaRtnetr. 2002. Effects of grazing intensity on growth, reproduction, and abundance of three palatable forbs in Kansas tallgrass prairie. Plant Ecology 159:23-33.

Hickman, K. R., D. C. Hartnett, R. C. Cochran, and C. E. Owensby. 2004. Grazing management effects on plant species diversity in tallgrass prairie. Journal of Range Management 57:58-65.

HobBs, N. T., D. S. Schimel, C. E. Owensby, and D. S. OJima. 1991. Fire and grazing in the tallgrass prairie: contingent effects on nitrogen budgets. Ecology 72:1374-1382.

Hoogland, J. L. 1995. The black-tailed prairie dog: social life of a burrowing mammal. Chicago, IL, USA: University of Chicago Press. 557 p. 
Hooper, D. U., F. S. Chapin, III, J. J. Ewel, A. Hector, P. Inchausti, S. Lavorel, J. H. Lawton, D. M. Lodge, M. Loreau, S. Naeem, B. Schmid, H. Setälä, A. J. Symstad, J. Vandermeer, and D. A. Wardle. 2005. Effects of biodiversity on ecosystem functioning: a consensus of current knowledge. Ecological Monographs 75:3-35.

Jackson, L. E., J. C. Kurtz, AND W. S. Fisher [EDS.]. 2000. Evaluation guidelines for ecological indicators. Research Triangle Park, NC, USA: US Environmental Protection Agency, Office of Research and Development, EPA/620/R-99/005. 107 p.

Johnson-Nistler, C. M., B. F. Sowell, H. W. Sherwood, and C. L. Wambolt. 2004. Black-tailed prairie dog effects on Montana's mixed-grass prairie. Journal of Range Management 57:641-648.

KIRSCH, L. M., and A. D. Kruse. 1973. Prairie fires and wildlife. Proceedings of the Tall Timbers Fire Ecology Conference; 8-9 June 1972; Lubbock, TX, USA. Tallahassee, FL, USA: Tall Timbers Research Station. p. 289303.

KLIPPLE, G. E., AND D. F. Costello. 1960. Vegetation and cattle responses to different intensities of grazing on short-grass ranges on the central Great Plains. USDA Forest Service Technical Bulletin Number 1216.

Knapp, A. K., J. M. Briggs, J. M. BlalR, and C. L. Turner. 1998a. Patterns and controls of aboveground net primary production in tallgrass prairie. In: A. K. Knapp, J. M. Briggs, D. C. Hartnett, and S. L. Collins [EDS.]. Grassland dynamics: long-term ecological research in tallgrass prairie. New York, NY, USA: Oxford University Press. p. 193-221.

Knapp, A. K., J. M. Briggs, D. C. Hartnett, and S. L. Collins. 1998b. Grassland dynamics: long-term ecological research in tallgrass prairie. New York, NY, USA: Oxford University Press.

Knapp, A. K., P. A. Fay, J. M. Blair, S. L. Collins, M. D. Smith, J. D. Carlisle, C. W. Harper, B. T. Danner, M. S. Lett, and J. K. McCarron. 2002. Rainfall variability, carbon cycling, and plant species diversity in a mesic grassland. Science 298:2202-2205.

Knapp, A. K., and T. R. Seastedt. 1998. Grasslands, Konza Prairie, and long-term ecological research. In: A. K. Knapp, J. M. Briggs, D. C. Hartnett, and S. L. Collins [EDS.]. Grassland dynamics: Iong-term ecological research in tallgrass prairie. New York, NY, USA: Oxford University Press. p. 3-15.

KNapp, A. K., AND M. D. Smith. 2001. Variation among biomes in temporal dynamics of aboveground primary production. Science 291:481-484.

Knops, J. M. H. 2006. Fire does not alter vegetation in infertile prairie. Oecologia 50:477-483.

Kotliar, N. B., B. W. Baker, A. D. Whicker, and G. Plumb. 1999. A critical review of assumptions about the prairie dog as a keystone species. Environmental Management 24:177-192.

KUCERA, C. L. 1956. Grazing effects on composition of virgin prairie in north-central Missouri. Ecology 37:389-391.

Lauenroth, W. K., I. C. Burke, and M. P. Gutmann. 1999. The structure and function of ecosystems in the central North American grassland region. Great Plains Research 9:223-259.

Laughim, D. C., And M. M. Moore. 2009. Climate-induced temporal variation in the productivity-diversity relationship. Oikos 118:897-902.

Lorenz, R. J., AND G. A. Rogler. 1972. Forage production and botanical composition of mixed prairie as influenced by nitrogen and phosphorus fertilization. Agronomy Journal 64:244-249.

LudWIG, J. A., AND G. N. BAstin. 2008. Rangeland condition: its meaning and use. A Discussion Paper prepared for the Australian Collaborative Rangelands Information System (ACRIS) Management Committee. Available at: http:// www.environment.gov.au/land/publications/acris/rangelands-condition.html. Accessed 2 February 2011.

MacDougall, A. S., and R. Turkington. 2005. Are invasive species the drivers or passengers of change in degraded ecosystems? Ecology 86:42-55.

MagurRan, A. E. 2004. Measuring biological diversity. Oxford, United Kingdom: Blackwell Publishing. $179 \mathrm{p}$.

Manier, D. J., And N. T. HobBs. 2006. Large herbivores influence the composition and diversity of shrub-steppe communities in the Rocky Mountains, USA. Oecologia 146:641-651.

Martin, J., M. C. Runge, J. D. Nichols, B. C. Lubow, and W. L. Kendall. 2009. Structured decision making as a conceptual framework to identify thresholds for conservation and management. Ecological Applications 19: 1079-1090.

Martinsen, G. D., J. H. Cushman, and T. G. Whitham. 1990. Impact of pocket gopher disturbance on plant species diversity in a shortgrass prairie community. Oecologia 83:132-138.

McCulley, R., I. C. Burke, and W. K. Lauenroth. 2009. Conservation of nitrogen increases with precipitation across a major grassland gradient in the central Great Plains of North America. Oecologia 159:571-581.

McNaughton, S. J. 1977. Diversity and stability of ecological communities: a comment on the role of empiricism in ecology. American Naturalist 111:515-525.

Milchunas, D. G., and W. K. Lauenroth. 1993. Quantitative effects of grazing on vegetation and soils over a global range of environments. Ecological Monographs 63:328-366.

Milchunas, D. G., W. K. Lauenroth, And I. C. BuRke. 1998. Livestock grazing: animal and plant biodiversity of shortgrass steppe and the relationship to ecosystem function. Oikos 83:65-74.

Mllchunas, D. G., W. K. Lauenroth, I. C. Burke, and J. K. Detling. 2008. Effects of grazing on vegetation in the shortgrass steppe. In: W. K. Lauenroth and I. C. Burke [EDS.]. Ecology of the shortgrass steppe: a long-term perspective. New York, NY, USA: Oxford University Press. p. 389-446.

Milchunas, D. G., W. K. Lauenroth, P. L. Chapman, and M. K. Kazempour. 1989. Effects of gazing, topography, and precipitation on the structure of a semiarid grassland. Vegetatio 80:11-23.

Milchunas, D. G., W. K. Lauenroth, P. L. Chapman, and M. K. Kazempour. 1990. Community attributes along a perturbation gradient in a shortgrass steppe. Journal of Vegetation Science 1:375-384.

Milchunas, D. G., And I. Noy-Meir. 2004. Geologic grazing refuges and grassland diversity: a case study from the shortgrass steppe. Journal of Range Management 57:141-147.

Milchunas, D. G., O. E. Sala, and W. K. Lauenroth. 1988. A generalized model of the effects of grazing by large herbivores on grassland community structure. American Naturalist 132:87-106.

Milne-Laux, S., and R. A. Sweitzer. 2006. Experimentally induced colony expansion by black-tailed prairie dogs (Cynomys ludovicianus) and implications for conservation. Journal of Mammalogy 87:296-303.

Morrison, L. C., J. D. DuBois, And L. A. KapustKa. 1986. The vegetational response of a Nebraska Sandhills grassland to a naturally occurring fall burn. Prairie Naturalist 18:179-184.

Myers, J. A., And K. E. Harms. 2009. Seed arrival, ecological filters, and plant species richness: a meta-analysis. Ecology Letters 12:1250-1260.

Oesterheld, M., J. Loreti, M. Semmartin, and J. M. Paruelo. 1999. Grazing, fire and climate effects on primary productivity of grasslands and savannas. In: L. R. Walker [ED.]. Ecosystems of disturbed ground. New York, NY, USA: Elsevier. p. 287-306.

Parton, W. J., J. A. Morgan, G. M. Wang, and S. Del Grosso. 2007. Projected ecosystem impact of the Prairie Heating and $\mathrm{CO}_{2}$ Enrichment experiment. New Phytologist 174:823-834.

Pellant, M., P. Shaver, D. A. Pyke, and J. E. Herrick. 2005. Interpreting indicators of rangeland health, version 4. Denver, CO, USA: US Department of the Interior, Bureau of Land Management, National Science and Technology Center, BLM/ W0/ST-00/001+1734/REV05. 122 p.

Plumb, G. E., AND J. L. DodD. 1993. Foraging ecology of bison and cattle on a mixed prairie: implications for natural area management. Ecological Applications 3:631-643.

Potvin, M. A., and A. T. HarRIson. 1984. Vegetation and litter changes of a Nebraska Sandhills prairie protected from grazing. Journal of Range Management 37:55-58.

Rapport, D. J., H. A. Regier, And T. C. Hutchinson. 1985. Ecosystem behavior under stress. American Naturalist 125:617-640.

Rebollo, D., D. G. Milchunas, I. Noy-Meir, and P. L. Chapman. 2002. The role of a spiny plant refuge in structuring grazed shortgrass steppe plant communities. Oikos 98:53-64.

Redmann, R. E. 1978. Plant and soil water potentials following fire in a northern mixed grassland. Journal of Range Management 31:443-445. 
Risser, P. G., E. C. Birney, H. D. Blocker, S. W. May, W. J. Parton, and J. A. Wiens. 1981. The true prairie ecosystem. Stroudsburg, PA, USA: Hutchinson Ross Publishing Company. $557 \mathrm{p}$.

Samson, F. B., and F. L. Knopf. 1994. Prairie conservation in North America. BioScience 44:418-421.

Scheintaub, M. R., J. D. Derner, E. F. Kelly, and A. K. Knapp. 2009. Response of the shortgrass steppe plant community to fire. Journal of Arid Environments 73:1136-1143.

Schimel, D. S., M. Keller, P. Duffy, L. Alves, S. Aulenbach, W. Gram, B. Johnson, T. Hehn, T. Kampe, B. Kao, M. Kuester, H. Loescher, V. McKenzie, and H. Powell. 2009. The NEON strategy. Boulder, CO, USA: NEON, Inc. 50 p.

Schmid, B., P. Balvanera, B. J. Cardinale, J. Godbold, A. B. Pfisterer, D. Raffaelli, M. Solan, and D. S. SRivastava. 2009. Consequences of species loss for ecosystem functioning: meta-analyses of data from biodiversity experiments. In: S. Naeem, D. E. Bunker, A. Hector, M. Loreau, and C. Perrings [eds.]. Biodiversity, ecosystem functioning, and human wellbeing. Oxford, United Kingdom: Oxford University Press. p. 14-29.

Seastedt, T. R., J. M. Briggs, and D. J. Gibson. 1991. Controls of nitrogen limitation in tallgrass prairie. Oecologia 87:72-79.

Shay, J., D. Kunec, and B. Dyck. 2001. Short-term effects of fire frequency on vegetation composition and biomass in mixed prairie in south-western Manitoba. Plant Ecology 155:157-167.

Smith, M. D., and A. K. Knapp. 1999. Exotic plant species in a $\mathrm{C}_{4}$-dominated grassland: invasibility, disturbance, and community structure. Oecologia 120:605-612.

StapP, P. 1998. A reevaluation of the role of prairie dogs in Great Plains grasslands. Conservation Biology 12:1253-1259.

Steuter, A. A., And L. Hidinger. 1999. Comparative ecology of bison and cattle on mixed-grass prairie. Great Plains Research 9:329-342.

Stohlgren, T. J., D. Binkley, G. W. Chong, M. A. Kalkhan, L. D. Schell, K. A. Bull, Y. Otsuki, G. Newman, M. Bashkin, and Y. Son. 1999. Exotic plant species invade hot spots of native plant diversity. Ecological Monographs 69:25-46.

Suding, K. N., S. L. Collins, L. Gough, C. Clark, E. E. Cleland, K. L. Gross, D. G. Milchunas, and S. C. Pennings. 2005. Functional- and abundance-based mechanisms explain diversity loss due to $\mathrm{N}$ fertilization. Proceedings of the National Academy of Sciences 102:4387-4392.

TILMAN, D. 1987. Secondary succession and the pattern of plant dominance along experimental nitrogen gradients. Ecological Monographs 57:189.

TILMAN, D. 1993. Species richness of experimental productivity gradients: how important is colonization limitation? Ecology 74:2179-2191.

Tilman, D., and A. El Hadd. 1992. Drought and biodiversity in grasslands. Oecologia 89:257-264.

Tilman, D., P. Reich, J. Knops, D. Wedin, T. Mielke, and C. Lehman. 2001. Diversity and productivity in a long-term grassland experiment. Science 294:843-845.

Tilman, D., P. B. Reich, And J. M. H. Knops. 2006. Biodiversity and ecosystem stability in a decade-long grassland experiment. Nature 441:629-632.

Tilman, D., And D. Wedin. 1991. Oscillations and chaos in the dynamics of a perennial grass. Nature 353:653-655.

Toombs, T. P., J. D. Derner, D. J. Augustine, B. Krueger, and S. Gallagher. 2010. Managing for biodiversity and livestock. Rangelands 32:10-15.

Towne, E. G., D. C. Hartnett, and R. C. Cochran. 2005. Vegetation trends in tallgrass prairie from bison and cattle grazing. Ecological Applications 15:1550-1559.
Towne, E. G., and K. E. Kemp. 2003. Vegetation dynamics from annually burning tallgrass prairie in different seasons. Journal of Range Management $56: 185-192$.

Towne, E. G., AND K. E. Kemp. 2008. Long-term response patterns of tallgrass prairie to frequent summer burning. Rangeland Ecology \& Management 61:509-520.

Truett, J. C., M. Phillips, K. Kunkel, And R. Miller. 2001. Managing bison to restore biodiversity. Great Plains Research 11:123-144.

[USDA-NRCS] US Department of Agriculture Natural Resources Conservation SERVICE. 1997. USDA-NRCS [EDS.]. National range and pasture handbook. Washington, DC, USA: USDA-NRCS Grazing Lands Institute.

Weaver, J. E., and R. W. Darland. 1948. Changes in vegetation and production of forage resulting from grazing lowland prairie. Ecology 29:1-29.

Weltzin, J. F., S. L. Dowhower, and R. K. Heitschmidt. 1997. Prairie dog effects on plant community structure in southern mixed-grass prairie. Southwestern Naturalist 42:251-258.

WEST, N. E. 1993. Biodiversity of rangelands. Journal of Range Management 46:2-13.

WhISENANT, S. W. 1999. Repairing damaged wildlands: a process-oriented, landscape-scale approach. Cambridge, United Kingdom: Cambridge University Press. $312 p$.

Whitford, W. G., A. G. DeSoyza, J. W. Van Zee, J. E. Herrick, and K. M. Havstad. 1998. Vegetation, soil, and animal indicators of rangeland health. Environmental Monitoring and Assessment 51:179-200.

Wienk, C., A. Thorstenson, J. Freeman, and D. Swanson. 2009. Northern Great Plains Fire Ecology Program review 1997-2007. Omaha, NE, USA: US Department of Interior, National Park Service, Midwest Regional Office, Fire \& Aviation Management, Internal Report. $215 \mathrm{p}$.

Willms, W. D., J. F. Dormaar, B. W. Adams, and H. E. Douwes. 2002. Response of the mixed prairie to protection from grazing. Journal of Range Management $55: 210-216$

WILSON, S. D. 2007. Competition, resources, and vegetation during 10 years in native grassland. Ecology 88:2951-2958.

WILSON, S. D., AND J. M. ShaY. 1990. Competition, fire, and nutrients in a mixedgrass prairie. Ecology 71:1959-1967.

Winter, S. L., J. F. Cully, JR., And J. S. Pontius. 2002. Vegetation of prairie dog colonies and non-colonized short-grass prairie. Journal of Range Management 55:502-508.

Wolfe, C. W. 1973. Effects of fire on a Sand Hills grassland environment. Proceedings of the Tall Timbers Fire Ecology Conference; 8-9 June 1972; Lubbock, TX, USA. Tallahassee, FL, USA: Tall Timbers Research Station. p. 241-255.

Wright, H. A., and A. W. Bailey. 1980. Fire ecology and prescribed burning in the Great Plains-a research review. Ogden, UT, USA: US Department of Agriculture, Forest Service, INT-GTR-77. 60 p.

WrIGHT, J. R. 1976. Range fertilization in the northern Great Plains. Journal of Range Management 29:180-185.

Zavaleta, E. S., J. R. Pasari, K. B. Hulvey, and G. D. Tilman. 2010. Sustaining multiple ecosystem functions in grassland communities requires higher biodiversity. Proceedings of the National Academy of Sciences (USA) 107:1443-1446.

Zvereva, E. L., E. Toivonen, and M. V. Kozlov. 2008. Changes in species richness of vascular plants under the impact of air pollution: a global perspective. Global Ecology and Biogeography 17:305-319. 